\title{
ANÁLISE FINANCEIRA EM PROPRIEDADES LEITEIRAS NO ESTADO DE GOIÁS
}

\author{
CLAYTON LUIZ DE MELO NUNES
}

Engenhe i ro Agrônomo

Orientador: Prof. Dr. MARCOS SAWAYA JANK

Dissertação apresentada à Escola Superior de Agricultura "Luiz de Queiroz", Universidade de São Paulo, para obtenção do título de Mestre em Ciências, Área de Concentração: Economia Aplicada.

P I R A C I C A B A

Estado de São Paulo - Brasil

Julho -2002 


\title{
Dados Internacionais de Catalogaçāo na Publicação (CIP) DIVISĀO DE BIBLIOTECA E DOCUMENTAÇĀO - ESALQ/USP
}

\author{
Nunes, Clayton Luiz de Melo \\ Análise financeira em propriedades leiteiras no Estado de Goiás / Clayton Luiz de \\ Melo Nunes. - - Piracicaba, 2002. \\ 80 p. \\ Dissertação (mestrado) - - Escola Superior de Agricultura Luiz de Queiroz, 2002. \\ Bibliografia. \\ 1. Agropecuária - Aspectos econômicos 2. Capital (Economia) 3. Custo \\ econômico 4. Leite - Aspectos econômicos 5. Propriedade rural - Planejamento \\ I. Título
}

CDD 338.1771

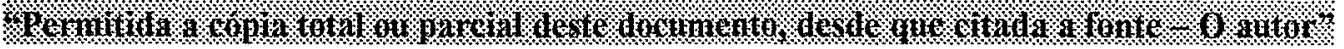


Dedico

À minha mãe Imarina, minha tia Iraci, aos meus irmãos Leonardo e Giovanni e a minha sobrinha Lara Francis. 


\section{AGRADECIMENTOS}

A DEUS que está sempre comigo, orientando e guiando-me pela vida, dando-me muita paz e serenidade para superar as dificuldades encontradas e iluminando meus caminhos.

Ao Prof. Marcos Sawaya Jank, pela amizade, orientação, incentivo e motivação constante para realização deste mestrado.

Aos Professores Zilda Paes de Barros Mattos, Evaristo Marzabal Neves, José Ferreira de Noronha, Dorival Gomes Geraldine e Renato Pinto da Silva Junior pelas críticas e sugestões indispensáveis que em muito contribuíram para realização e aperfeiçoamento deste estudo.

Meus agradecimentos a todos os Professores do Departamento de Economia, Administração e Sociologia Rural da ESALQ/USP, pela oportunidade, ensinamento e condições de trabalho oferecidas.

Aos funcionários do Departamento que estiveram sempre prontos a ajudar: Cristiane, Elenice, Helena, Ligiana, Luciane, Maielli, Pedro e Valdeci.

A todos os colegas e grandes amigos da turma de pós-graduação em Economia Aplicada, pela amizade, companheirismo e estímulo, especialmente a Alexandre (Conchas), Carlos Magri, Cinthia, Cristiane, Dilson, Patrick, Simone e Valeriana. Aos demais colegas de pós-graduação, pela agradável convivência.

Expresso minha sincera gratidão, respeito e admiração aos familiares e amigos que não deixaram de incentivar um só momento. Especialmente a minha mãe Imarina Pereira de Melo, minha tia Iraci Melo de Camargo, irmãos Giovanni Luiz Nunes e Leonardo Pereira de Souza, a minha namorada Carina Andréia da Costa e aos amigos 
Eduardo Veras de Araújo, Gisele Macedo e Silva, Marcelo Theoto Rocha e Valter Bertini Galan.

Aos Amigos do Setor de Economia e Administração Rural da Escola de Agronomia da Universidade Federal de Goiás e ao programa PICDT/UFG/CAPES.

Finalmente, a todos que de uma forma ou de outra, participaram da concretização deste sonho. 


\section{SUMÁRIO}

LISTA DE FIGURAS .................................................................. vii

LISTA DE QUADROS ..................................................................... viii

LISTA DE TABELAS ................................................................... ix

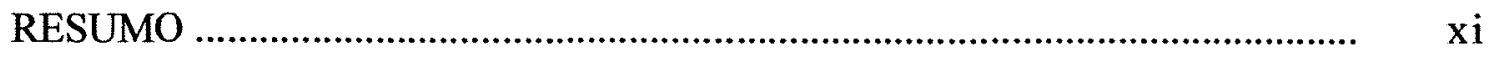

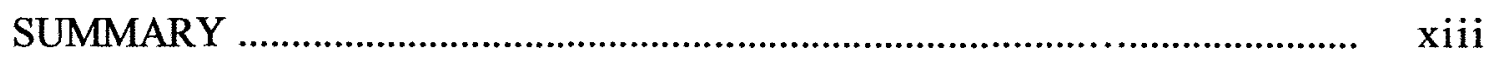

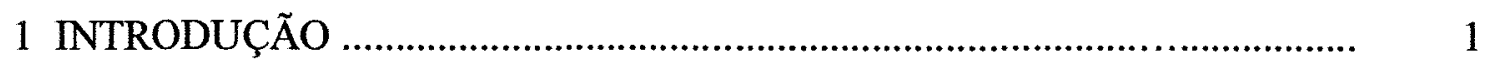

1.1 Importância do Estudo .................................................................... 5

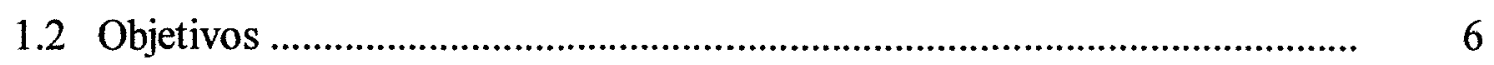

2 EVOLUÇÃO DA PECUÁRIA LEITEIRA EM GOIÁS ................................. 7

3 REVISÃO DE LITERATURA ............................................................... 15

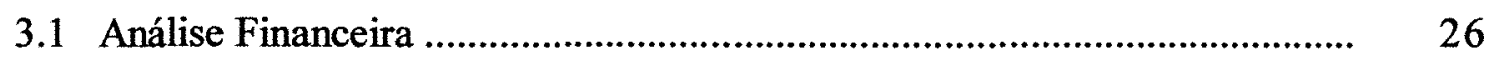

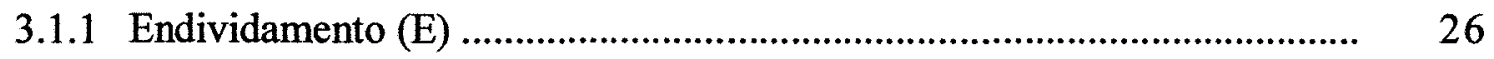

3.1.2 Retorno do capital total (RCT) …..................................................... 28

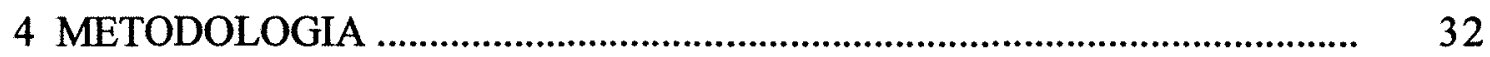

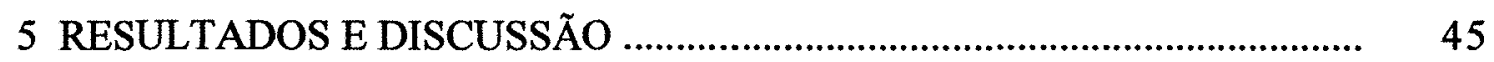

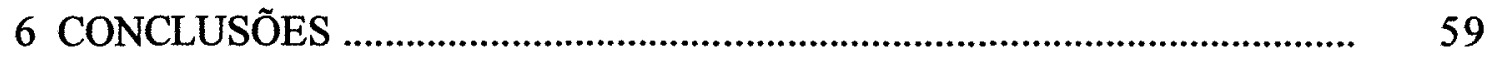

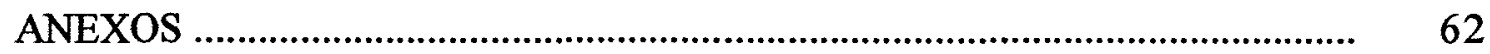

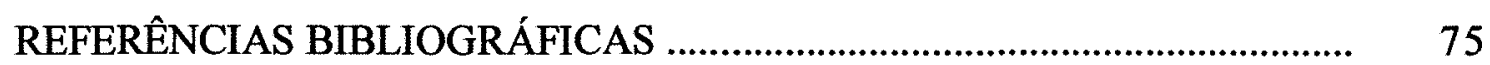




\section{LISTA DE FIGURAS}

Página

1 Organograma das informações segundo suas origens ....................................... 16

2 Composição do custo total de produção de propriedades leiteiras no Estado de Goiás, de 1997/99

3 Composição percentual do custo total de produção de propriedades leiteiras no Estado de Goiás, segundo o nível de produção, de 1997/99

4 Taxa de Crescimento do ativo, em percentagem, de propriedades leiteiras no Estado de Goiás, de 1997/99 


\section{LISTA DE QUADROS}

Página

1 Distribuição da amostra segundo a Mesorregião, conforme a estratificação ...... 34

2 Modelo da Estrutura do Balanço Patrimonial utilizado para Propriedades

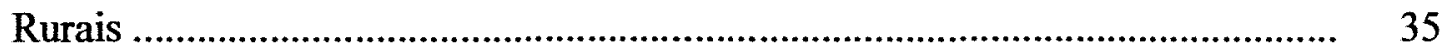

3 Modelo da Estrutura da Demonstração de Resultado de Exercício utilizado para Propriedades Rurais 


\section{LISTA DE TABELAS}

Página

1 Estrutura do PIB, em percentagem, do Estado de Goiás - 1994-97 ..................... 1

2 Valor Bruto da Produção, em R\$1000,00, dos principais produtos . 2 agropecuários do Estado de Goiás, 1995 - 1998

3 Produção mundial de leite. Principais países produtores, 1995 a 1999

4 Consumo nacional per capita de leite fluido, queijo e leite em pó desnatado, em kg/pessoa/ano, no período de 1992 a 1999

5 Produção total e produtividade de leite no Brasil e nos principais estados produtores de leite, 1998

6 Participação relativa de alguns estados na produção de leite no período de $1990 / 1998$

7 Indicadores da evolução da pecuária leiteira goiana no período de 1985 a 1996.10

8 Produção de leite no Brasil e Goiás e respectivas taxas de crescimento, 1989 a 1998

9 Produção de leite das Messoregiões do Estado de Goiás e participação relativa desta produção, 1995 a 1998

10 Efetivo do rebanho bovino, vacas ordenhadas, produção de leite e produtividade por Microrregião do Estado de Goiás - 1994

11 Principais Municípios produtores de leite, efetivo bovino, vacas ordenhadas, produção de leite e produtividade em Goiás, 1994

12 Características gerais das propriedades leiteiras do Estado de Goiás, comparadas a outras pesquisas

13 Indicadores de especialização da produção leiteira, em percentual, estratificados por nível de produção, comparados a outras pesquisas 
14 Composição percentual do custo total de produção de propriedades leiteiras no Estado de Goiás, no período de outubro de 1997 a setembro de 1999

15 Composição percentual do custo total de produção de propriedades leiteiras no Estado de Goiás, segundo o nível de produção, no período de outubro de 1997 a setembro de 1999

16 Custo médio de produção e preços recebidos, em $\mathrm{R} \$$ por litros, Estado de Goiás, 1997/99.

17 Lucratividade total da atividade leiteira, em R\$ por mês, segundo o tamanho do produtor, no Estado de Goiás, 1997/99

18 Grau de endividamento de propriedades leiteira, em percentagem, segundo o tamanho do produtor, no Estado de Goiás, 1997/99

19 Margem líquida sobre vendas, giro do ativo e retorno do capital total de propriedades leiteira, segundo o tamanho do produtor, no Estado de Goiás, 1997/99 


\title{
ANÁLISE FINANCEIRA EM \\ PROPRIEDADES LEITEIRAS NO ESTADO DE GOIÁS
}

\author{
Autor: CLAYTON LUIZ DE MELO NUNES \\ Orientador: Prof. MARCOS SAWAYA JANK
}

\section{RESUMO}

Este trabalho consta de seis capitulos. O primeiro introduz a importância do estudo e seus objetivos. O segundo capítulo é formado pelo referencial teórico que fundamenta o trabalho. O terceiro capítulo traz a metodologia utilizada. No quarto capítulo, é abordada a evolução do leite em Goiás, bem como a produção dos municípios goianos. Já no quinto capítulo faz-se uma caracterização da amostra, comparando-a a outros estudos, e evidencia-se os resultados e suas discussões. Para finalizar, o último capítulo traz as conclusões. A maioria dos produtores não utiliza nenhum critério para verificar o resultado econômico de sua atividade. Desta forma, analisar os ganhos ou perdas que os produtores estão auferindo da atividade leiteira é importante para melhor planejar o desenvolvimento do setor agropecuário. $O$ objetivo principal desta dissertação é analisar a situação econômica de um grupos de propriedades rurais voltadas à atividade leiteira, não só por meio do custo econômico, mas também utilizando-se de indicadores contábeis como o nível de endividamento, o retorno sobre o investimento, o giro do ativo e a margem líquida sobre vendas. A metodologia se apoia em estudo de casos. $O$ 
levantamento dos dados foi feito mensalmente, durante o período de outubro de 1997 a setembro de 1999. Utilizou-se como modelos as análises de custo econômico, de rentabilidade e de balanço patrimonial. Com base nos casos estudados as principais conclusões foram: a) a utilização de tecnologia mais avançada não levou à maior rentabilidade; b) o aumento da produção permitiu uma diminuição do endividamento e c) a maioria dos produtores melhorou o retorno sobre o ativo através do aumento tanto da margem líquida sobre vendas como do giro do ativo. 
FINANCE ANALYZE IN THE

\title{
MILK FARM IN THE STATE OF GOIÁS
}

\author{
Author: CLAYTON LUIZ DE MELO NUNES
}

Adviser: Prof. MARCOS SAWAYA JANK

\section{SUMMARY}

This research has six chapters. The first is an introduction where the importance and the objectives are shown. The second chapter discusses the research's theoretical framework. The third shows the methodology used. The fourth chapter presents milk production trend in the state of Goiás as well as in specific counties. In the fifth chapter the farm sample is characterized and compared with other studies and the results presented. Finally, the sixth chapter presents the conclusions. The majority of the producers use no criteria to verify the economic results of their activity. Therefore, to analyze their gains or losses in this activity is important to better plan the development of milk production in the agricultural sector. The main objective of this dissertation is to analyze the economic results of a group of dairy farms, using economic cost as well as accounting ration such as debt level, return on investment, asset turnover, and net margin/sales ratio. The methodology used was the case study approach. Data were collected on a monthly basis during the period from October 1997 to September 1999. Economic cost, profitability and networth statement were utilized as the basic models. 
The main conclusions were the following: a) the use of more advanced technology did not explain higher profitability; b) increase in production level reduced the level of debt and c) most producers increased their rate of return on assets by increasing both net margin over sales as well as asset turnover ratios. 


\section{INTRODUÇÃo}

O Estado de Goiás tem o setor agropecuário como sua principal fonte geradora de renda. Observando-se a estrutura do PIB no período de 1990 a 1997, verifica-se um aumento da participação do setor agropecuário no PIB do estado da ordem de $3,88 \%$ a.a., enquanto que os demais setores experimentaram taxa de crescimento negativa durante o mesmo período (Tabela 1). Várias são as atividades agropecuárias desenvolvidas, mas, sem dúvida, nenhum outro produto cresceu tanto no Estado como o leite, com uma taxa de crescimento sob inspeção federal de $76 \%$ entre 1990 e 1997 (Bressan et al., 1999). Segundo o IBGE (1997), em 1995-1996 as atividades de pecuária bovina desenvolveram-se em estabelecimentos de todos os tamanhos ${ }^{1}$, mas com acentuada concentração nas médias e grandes propriedades.

Tabela 1. Estrutura do PIB, em percentagem, do Estado de Goiás - 1994-97.

\begin{tabular}{|c|c|c|c|c|c|c|c|c|c|}
\hline \multirow{2}{*}{ SETORES } & \multicolumn{8}{|c|}{ ANOS } & \multirow{2}{*}{$\begin{array}{c}\text { Tx } \\
\text { Cresc } \\
\text { (\%aa) }\end{array}$} \\
\hline & 1990 & 1991 & 1992 & 1993 & 1994 & 1995 & 1996 & 1997 & \\
\hline & 20.5 & 17.2 & 17.5 & 18.2 & 27.6 & 28.2 & 27.5 & 27.8 & 3.88 \\
\hline Indústri & 14.5 & 10.8 & 11.5 & 7.6 & 10.0 & 12.0 & 12.6 & 12.8 & -1.55 \\
\hline Serviços & 65.0 & 72.0 & 71.0 & 14.2 & 62.4 & 59.8 & 59.9 & 59.4 & -1.12 \\
\hline
\end{tabular}

Fonte: SEPLAN-GO/SEPIN, 1999

\footnotetext{
${ }^{1}$ Em Goiás, 60,5\% do número dos estabelecimentos rurais com menos de 100 ha ocupam $9,2 \%$ da área total; já $34,6 \%$ do número de estabelecimentos com 100 ha até menos de 1000 ha ocupam $43,70 \%$ da área total e para estabelecimentos acima de 1000 ha, o número representa $4,9 \%$ no total de estabelecimentos e $47,1 \%$ na área total (IBGE, 1997).
} 
A pecuária de leite sempre esteve entre as quatro atividades agropecuárias mais importantes para o estado, chegando a ser a atividade de maior valor bruto da produção em 1996. Em 1997, passou a ser a terceira atividade agropecuária, em valor bruto da produção, ficando atrás da soja e do milho, mas recuperou uma posição em 1998, ficando somente atrás da soja (Tabela 2).

Tabela 2. Valor Bruto da Produção, em R\$ 1000,00, dos principais produtos agropecuários do Estado de Goiás, 1995 - 1998.

\begin{tabular}{lllll}
\hline \multicolumn{1}{c}{ Produtos } & 1.995 & 1.996 & 1.997 & 1.998 \\
\hline Leite & $275.434,93$ & $384.784,45$ & $349.569,29$ & $371.550,45$ \\
Cana-de-açúcar & $132.094,00$ & $141.637,00$ & $150.878,00$ & $187.279,00$ \\
Milho (em grão) & $318.357,00$ & $367.424,00$ & $374.212,00$ & $311.303,00$ \\
Soja (em grão) & $261.755,00$ & $383.247,00$ & $577.510,00$ & $713.401,00$ \\
\hline
\end{tabular}

Fonte: SEPLAN-GO/SEPIN, 1995/1996/1997/1998

A região Centro-Oeste produz 15\% do leite do Brasil (Brandão, 1999) e o estado de maior destaque é Goiás, com $11 \%$ da produção nacional e $71 \%$ da produção da região (Gomes, 1999). Segundo o Censo Agropecuário de 1995-1996, o estado possui 79.522 produtores com uma produção média anual de 23.013 litros, aproximadamente 63 litros de leite por dia. A produtividade média no estado é de 1.184 litros por vaca ordenhada por ano. Goiás exporta cerca de $90 \%$ de sua produção e em 1997 superou a produção de São Paulo e passou a ser o segundo estado maior produtor de leite do Brasil (Balde Branco, junho 1997), ficando atrás somente de Minas Gerais.

Dentre os fatores que impulsionaram a atividade leiteira, destacam-se as condições favoráveis nos financiamentos de origem governamental, baixo preço da terra, condições edafoclimáticas favoráveis à produção de forragens, oferta de grãos a preços competitivos, boa localização dos centros consumidores e crises na atividade de bovinocultura de corte, que seriam responsáveis pela migração de um grande contingente de produtores para a atividade leiteira (Jank et al., 1999).

Apesar dos vários indicadores favoráveis ao desenvolvimento da atividade leiteira no Estado, deve-se questionar o excesso de euforia por parte de 
produtores que, aparentemente, estão investindo seus recursos de forma desordenada, comprando animais de qualidade contestável ou construindo instalações desnecessárias, o que pode provocar um retrocesso na situação atual da atividade, resultando consequentemente em dificuldades econômicas e sociais ao setor agropecuário.

$\mathrm{O}$ crescimento da produção de leite em Goiás, tanto através de aumento da produção de pecuaristas tradicionais como pelo excesso de euforia de muitos produtores que estão entrando na atividade após a liberação dos preços do leite, juntamente com o aumento da competição internacional e nacional, tendem a diminuir cada vez mais a margem de lucro da atividade, onde ela existe. As importações de leite, a eliminação dos subsídios por parte do Governo ao setor agrícola, com o conseqüente aumento do custo do dinheiro, também vem contribuindo para a diminuição da margem de lucro, obrigando o produtor rural a aprimorar seus métodos administrativos, contábeis e tecnológicos, para obter sucesso com o negócio agrícola, dando ênfase à qualidade e à competitividade.

Todos os elos da cadeia produtiva do setor leiteiro estão sendo submetidos a uma intensa modernização decorrente dos processos de abertura da economia brasileira, integração regional, liberação dos preços dos produtos lácteos, e da concorrência das importações do Mercosul e da União Européia. Autores como Vilela (1998), afirmam que essa modernização tem sido decisiva para que a atividade leiteira passe de uma fase extrativista para um modelo competitivo e sustentável.

O produtor está sendo desafiado a se afirmar como empreendedor competitivo e ajustado às constantes transformações técnicas e econômicas que se processam numa velocidade cada vez maior. De especialista em operações de cultivo e criação de animais o produtor terá que se transformar em empresário (Nunes et al., 1998).

Cada vez mais os produtores devem buscar responder à tríade do problema econômico: o que produzir, como produzir e para quem produzir. É necessário então, mudar o enfoque para um sistema interligado de produção, processamento e comercialização. $O$ desafio colocado para o produtor rural é reconhecer e assumir que faz parte de uma cadeia alimentar, na qual seguramente é o elo mais fraco. Esta cadeia 
precisa satisfazer o consumidor, colocando no mercado produtos de boa qualidade, mais elaborados, facilmente utilizáveis e a preços competitivos.

O problema é que muitos produtores não se adaptaram ou desconhecem essa realidade e continuam insistindo em manter o mesmo padrão administrativogerencial usado em décadas passadas, quando os subsídios, a inflação e os altos rendimentos nominais das aplicações financeiras mascaravam os verdadeiros resultados da atividade produtiva (Geraldine et al., 1999).

Segundo Procópio (1996, p. 19), “administrar uma atividade agropecuária requer ampla abrangência de informações em termos de desempenho fisico e financeiro. Algumas vezes, entretanto, muitas das informações necessárias são registradas apenas na memória de quem administra ou em anotações informais. Há também a tendência de algumas em julgar ou medir o desempenho financeiro de uma atividade rural pelo surgimento de novas construções, pela quantidade de terra que compõe a atividade ou pelo total de dinheiro no banco. Cada uma dessas medidas, todavia, propicia um quadro potencialmente enganoso de desempenho financeiro de um negócio agropecuário e muitas vezes uma análise errada da força financeira do proprietário do negócio".

$\mathrm{O}$ produtor de leite pode, em determinado momento, modificar suas atividades para conseguir maior integração no processo de produção. A informação contábil e a situação tecnológica, que configuram o estado da empresa no momento da mudança, devem servir como ponto de partida para uma nova situação (Geraldine et al., 1999). Segundo Lemes (1996, p. 30), "em contraposição a todos os investimentos privados realizados e à importância econômica da pecuária no Brasil, o que se percebe nas organizações que se dedicam a essa atividade é uma contabilidade insuficientemente explorada quanto ao seu poder de identificar, registrar, mensurar $e$ possibilitar a análise dos fatos ocorridos".

Segundo Walter \& Braga (1981), a contabilidade é um dos instrumentos utilizado pela administração especialmente concebido para coletar, registrar, acumular, resumir, medir e interpretar os fenômenos que afetam a situação patrimonial, financeira e econômica de qualquer empresa, seja qual for seu ramo de atividade ou forma jurídica. 
Segundo Assumpção \& Veiga (2000), a contabilidade fornece informações necessárias que ajudam nas tomadas de decisão da empresa. Assim, pode-se decidir em comprar ou alugar uma máquina, sobre contrair ou não uma dívida e até mesmo questões específicas que envolvem redução de custo, aumento de produção e outras.

As análises econômica e financeira da atividade leiteira conduzidas pelo administrador e empresário rural, individualmente e em grupos organizados, fornecem informações valiosas para ações corretivas das decisões, podendo, desta forma, identificar falhas na alocação dos recursos. Quando essas análises são feitas para uma amostra suficientemente grande de produtores, os resultados representam subsídios importantes aos órgãos representativos dos produtores bem como aos responsáveis pela formulação de politicas agrícolas (Nunes et al., 1999).

\section{1 Importância do Estudo}

O setor agropecuário é fundamental para o crescimento dos países do terceiro mundo. Particularmente, a atividade leiteira representa uma das alavancas responsáveis ao desenvolvimento econômico do Brasil e do Estado de Goiás. Dentro desta ótica, a profissionalização do setor agropecuário deve ser não só no âmbito tecnológico, mas também no âmbito gerencial. Como ponto inicial para essa profissionalização, conhecer o resultado econômico da atividade, quer seja pela análise de custo gerencial ou pela análise de balanço patrimonial, é necessário para tomar melhores decisões. Segundo Marion (1998), quando se investiga a forma como está funcionando o empreendimento, é comum constatar-se que, muitas vezes, o nó da questão não está somente nos pontos críticos mencionados, mas também na má gerência, ou seja, nas decisões tomadas sem respaldo, sem dados confiáveis.

Embora os indicadores contábeis são antigos e muito utilizados para verificar os negócios relacionados às empresas urbanas, ainda é pouco usado no setor 
rural, pois muitos produtores, por falta de conhecimento ou por comodidade, insistem em utilizar meios empíricos.

Diante disto, analisar o resultado econômico de propriedades rurais utilizando-se de indicadores contábeis torna-se um grande desafio. $O$ problema inicia-se em escolher indicadores que melhor significado e aplicabilidade possam trazer ao produtor rural, especificamente, os de maior relevância para analisar a atividade de pecuária leiteira, e relacioná-los com a análise de custos que alguns já utilizam para avaliar economicamente esta atividade.

\section{2 Objetivos}

O objetivo principal deste trabalho é analisar a situação econômica de grupos de propriedades rurais, voltadas à atividade leiteira, do Estado de Goiás, segundo o volume de produção, no período de outubro de 1997 a setembro de 1999.

Especificamente pretende-se avaliar comparativamente:

- a composição do custo econômico das propriedades;

- o nível de endividamento;

- a evolução do retorno sobre o capital total e

- $\quad$ giro do ativo e a margem líquida sobre vendas.

Como objetivo secundário, pretende-se fazer um estudo da evolução da atividade leiteira no Estado de Goiás, verificando alguns indicadores como a produção total do estado, produtividade anual por animal, produção média diária por propriedade, número de propriedades especializadas na atividade leiteira, número de vacas ordenhadas e número de propriedades com ordenhadeira mecânica. 


\section{EVOLUÇÃo DA PECUÁRIA LEITEIRA EM GOIÁS}

A produção mundial de leite está distribuída em 193 países, mas aproximadamente $58 \%$ desta produção, concentra-se em apenas 11 países (Tabela 3). Os Estados Unidos respondem por cerca de $15 \%$ da produção mundial, mas apresentou uma taxa de crescimento pequena quando comparada ao Brasil que aparece como $6^{\circ}$ maior produtor de leite desde 1995, e apresentou uma taxa de crescimento quase 7 vezes superior. A produção brasileira de leite apresentou taxa média anual de crescimento de $5,78 \%$, a maior taxa entre os seis países maiores produtores, com isso a participação da produção brasileira na produção mundial que era de 3,6\% em 1995 passou para 4,7\% em 1999.

Tabela 3. Produção mundial de leite. Principais países produtores, 1995 a 1999.

\begin{tabular}{lcrlllr}
\hline \multirow{2}{*}{\multicolumn{1}{c}{ País }} & \multicolumn{5}{c}{ Produção (milhões de toneladas) } & $\begin{array}{c}\text { Taxas de } \\
\text { Crescimento }\end{array}$ \\
\cline { 2 - 6 } & \multicolumn{1}{c}{1995} & \multicolumn{1}{c}{1996} & \multicolumn{1}{c}{1997} & \multicolumn{1}{c}{1998} & \multicolumn{1}{c}{1999} & \multicolumn{1}{c}{ (\% aa ) } \\
\hline Estados Unidos & 70.439 & 69.855 & 70.801 & 71.414 & 73.482 & 0,85 \\
Índia & 27.518 & 28.496 & 29.576 & 35.500 & 36.000 & 5,52 \\
Federação Russa & 39.098 & 35.521 & 33.834 & 32.924 & 31.700 & $(4,11)$ \\
Alemanha & 28.606 & 28.778 & 28.701 & 28.378 & 28.300 & $(0,21)$ \\
França & 25.738 & 25.108 & 24.916 & 24.741 & 24.700 & $(0,82)$ \\
Brasil & 16.985 & 19.089 & 20.600 & 21.630 & 22.495 & 5,78 \\
Reino Unido & 14.844 & 14.808 & 14.576 & 13.932 & 14.210 & $(0,87)$ \\
Polônia & 11.642 & 11.695 & 12.123 & 12.595 & 11.900 & 0,44 \\
Nova Zelândia & 9.285 & 10.010 & 11.058 & 11.084 & 11.372 & 4,14 \\
Países Baixo & 11.293 & 11.012 & 11.922 & 11.200 & 10.895 & $(0,71)$ \\
Itália & 11.285 & 10.798 & 10.876 & 10.876 & 10.876 & $(0,73)$ \\
Outros ${ }^{2}$ & 197.702 & 199.198 & 197.070 & 201.158 & 201.843 & 0,41 \\
Total (mundo) & 464.435 & 464.386 & 466.053 & 475.462 & 477.773 & 0,57 \\
\hline
\end{tabular}

Fonte: Food and Agriculture Organization of the United Nations - FAO

${ }^{1}$ Taxa geométrica de crescimento anual, calculada pela fórmula: $V_{n}=V_{0}(1+r)^{n}$ onde $V_{n}$ e $V_{0}$ são o valor final e inicial respectivamente de cada grandeza, $r$ é a taxa geométrica e $\mathbf{n}$ o número de períodos em anos.

${ }^{2}$ Compõe a produção de 182 países. 
O consumo per capita de leite fluido, queijo e leite em pó desnatado no Brasil, de 1992 a 1999, aumentou a uma taxa de crescimento de 6,28, 3,97 e 4,30\% ao ano respectivamente (Tabela 4). Em resposta ao ganho de renda do consumidor com a implantação do Plano Real, só no ano de 1995 o acréscimo foi de $25,88 \%$ para leite fluido, $20,78 \%$ para queijo e $17,91 \%$ para leite em pó desnatado.

Tabela 4. Consumo nacional per capita de leite fluido, queijo e leite em pó desnatado, em kg/pessoa/ano, no período de 1992 a 1999.

\begin{tabular}{lrrrrrrrrr}
\hline \multirow{2}{*}{ Produto } & \multicolumn{1}{c}{ Ano } & Taxa Cresc. \\
\cline { 2 - 9 } \multicolumn{1}{c|}{} & \multicolumn{1}{c}{ 1992 } & 1993 & 1994 & 1995 & 1996 & 1997 & 1998 & 1999 & (\% aa) \\
\hline Leite fluido & 49,24 & 51,70 & 54,49 & 68,59 & 70,08 & 73,55 & 77,14 & 80,18 & 6,28 \\
Queijo & 1,97 & 2,08 & 2,31 & 2,79 & 2,56 & 2,64 & 2,66 & 2,69 & 3,97 \\
Leite pó desnat & 0,45 & 0,50 & 0,57 & 0,67 & 0,79 & 0,61 & 0,62 & 0,63 & 4,30 \\
\hline
\end{tabular}

Fonte: FNP Consultoria \& Comércio, 1999

Aproximadamente $71 \%$ da produção leiteira nacional concentra-se em cinco estados, o que representa mais de 14,4 bilhões de litros de leite produzidos: O Estado de Minas Gerais é o maior produtor, mas o Rio Grande do Sul apresenta a melhor produtividade com 7,56 1/vaca/dia (Tabelas 5 e 6 ).

Tabela 5. Produção total e produtividade de leite no Brasil e nos principais estados produtores de leite, 1998.

\begin{tabular}{lccc}
\hline \multirow{2}{*}{ Estado } & Produção & \multicolumn{2}{c}{ Produtividade (litros/vaca) $^{\text {(bilhões de litros) }}$} \\
\cline { 3 - 4 } & 5,701 & dia $^{1}$ & /ano \\
\hline Minas Gerais & 2,195 & 5,75 & $2.097,6$ \\
Rio Grande do Sul & 2,209 & 7,56 & $2.757,7$ \\
São Paulo & 1,932 & 6,31 & $2.303,9$ \\
Paraná & 2,378 & 5,90 & $2.153,4$ \\
Goiás & 5,673 & 5,30 & $1.935,3$ \\
Demais Estados & 20,087 & 2,04 & 746,7 \\
Brasil & & 3,88 & $1.415,1$ \\
\hline
\end{tabular}

Fonte: FNP Consultoria \& Comércio, 1999

${ }^{1}$ Corresponde a lactação de 365 dias. Por esse critério a menor produtividade entre os estados brasileiros ocorre em Roraima com 0,65 litro/vaca/dia e 236,5 litros/vaca/ano, e a maior fica no Distrito Federal com 10,5 litros/vaca/dia e 3669,3 litros/vaca/ano 
Outra questão presente é que a pecuária de leite no Brasil vem se caracterizando pela migração de bacias tradicionais como as regiões sul e sudeste do País para regiões consideradas, até pouco tempo, com dificuldades para seu desenvolvimento. É o caso do Estado de Goiás que apresenta a menor produtividade, em termos de litros/vaca/dia, entre os cinco estados maiores produtores de leite, mas que de $5^{\circ}$ maior produtor em 1990 assume a $2^{a}$ posição em 1998 , com $11,8 \%$ da produção brasileira de leite, superando estados como São Paulo, Rio Grande do Sul e Paraná (Tabela 5 e 6).

Tabela 6. Participação relativa de alguns estados na produção de leite no período de $1990 / 1998$.

\begin{tabular}{lrrrrrrrrr}
\hline \multicolumn{1}{c}{ Estado } & \multicolumn{10}{c}{ Ano } \\
\cline { 2 - 9 } & 1990 & 1991 & 1992 & 1993 & 1994 & 1995 & 1996 & 1997 & 1998 \\
\hline Minas Gerais & 29,6 & 28,7 & 28,5 & 28,8 & 29,1 & 29,8 & 29,1 & 28,3 & 28,4 \\
Rio Grande do Sul & 13,8 & 13,3 & 12,6 & 12,8 & 12,6 & 10,4 & 10,8 & 11,1 & 10,9 \\
São Paulo & 9,6 & 10,0 & 10,1 & 10,2 & 10,1 & 12,0 & 11,4 & 11,2 & 11,0 \\
Paraná & 8,3 & 8,0 & 8,2 & 8,9 & 8,9 & 9,1 & 9,5 & 9,9 & 9,6 \\
Goiás & 7,6 & 8,0 & 8,2 & 8,9 & 8,9 & 9,4 & 10,7 & 11,3 & 11,8 \\
Demais Estados & 31,1 & 32,0 & 32,4 & 30,4 & 30,4 & 29,3 & 28,5 & 28,2 & 28,3 \\
\hline
\end{tabular}

Fonte: FNP Consultoria \& Comércio, 1999

Os indicadores da evolução de produção de leite no Estado de Goiás (Tabela 7), caracterizam nitidamente um comportamento agressivo no desenvolvimento desta atividade durante o período de 1985 a 1996, que praticamente dobrou a produção e a produtividade do rebanho bovino leiteiro e acrescentou $117,33 \%$ à produtividade média por propriedade dedicada à esta atividade.

A dinâmica de modificação da pecuária leiteira goiana, como um todo, vem ocorrendo de forma gradual e persistente, superando dificuldades e se ajustando às exigências do mercado. Sua evolução no período de 1985 a 1996, apresenta indicadores que sugerem que o setor leiteiro se desenvolveu no sentido da integração às exigências da modernização, trabalhando com percentual maior de rebanho com aptidão leiteira no 
processo produtivo $60,33 \%$, aumentando em mais de $37 \%$ o número de propriedades especializadas na produção leiteira, ao mesmo tempo que o percentual do rebanho de corte na produção caiu mais de $22 \%$. Na última coluna se expressa em termos de taxa geométrica de crescimento anual, parte da dinâmica da pecuária leiteira goiana, com significativo destaque de $27,5 \%$ a.a. na taxa de crescimento para a adoção de ordenhadeiras mecânicas, elevando-se de 183 para 2649 propriedades no período considerado. Chama a atenção que este dinamismo se deu, principalmente, pela melhoria da qualidade do rebanho, já que, as taxas de crescimento do número de propriedades produtoras e de vacas ordenhadas são baixas, enquanto tem-se expressivas taxas para a produtividade do rebanho e produção média por propriedade.

Tabela 7. Indicadores da evolução da pecuária leiteira goiana no período de 1985 a 1996.

\begin{tabular}{lrrrc}
\hline & \multicolumn{2}{c}{ Ano } & \multicolumn{2}{c}{ Variação } \\
\cline { 2 - 5 } \multicolumn{1}{c}{ Indicadores } & & & & $\begin{array}{c}\text { Taxa de } \\
\text { Crescimento } \\
\end{array}$ \\
& 1985 & 1996 & $\%$ & \\
& & & & \\
& & & & \\
& 1.055 & 2.033 & 92,65 & 6,15 \\
Produção (milhões de litros) & 669 & 1316 & 96,71 & 6,34 \\
Produtividade (litro/vaca/ano) & 36,42 & 79,15 & 117,33 & 7,31 \\
Produção média (litro/dia/propriedade) & 79.373 & 79.522 & 0,19 & \\
Propriedades produtoras de leite & 32.286 & 44.509 & 37,86 & $2, \overline{96}$ \\
Propriedades especializadas em leite & 1577 & 1545 & $(2,03)$ & $(0,18)$ \\
Vacas ordenhadas (mil cabeças) & 183 & 2.649 & 1348 & 27,50 \\
Propriedades com ordenhadeira mecânica & 45,76 & 60,33 & 31,84 & 2,54 \\
Participação do rebanho leiteiro & 38,71 & 29,90 & $(22,76)$ & $(1,88)$ \\
Participação do rebanho de corte & & & & \\
\hline
\end{tabular}

Fontes: Instituto Brasileiro de Geografia e Estatísticas - IBGE, Federação da Agricultura do Estado de Goiás - FAEG, Confederação Nacional da Agricultura - CNA, Leite Brasil

Apesar deste dinamismo o setor leiteiro goiano durante a década de noventa, chegou a ter taxa de crescimento zero da produção em 1994. Entretanto, nos anos subsequentes voltou a crescer aceleradamente, chegando a $25 \%$ em 1996, enquanto a produção brasileira de leite crescia a 10,46 \% naquele ano (Tabela 8). 
Tabela 8. Produção de leite no Brasil e Goiás e respectivas taxas de crescimento, 1989 a 1998

\begin{tabular}{ccccc}
\hline \multirow{2}{*}{ Ano } & \multicolumn{2}{c}{ Produção (bilhões de litros) } & \multicolumn{2}{c}{ Taxas de crescimento (\%) } \\
\cline { 2 - 5 } & Brasil & Goiás & Brasil & Goiás \\
\hline 1989 & 14,0 & 1,0 & - & - \\
1990 & 14,5 & 1,1 & 3,57 & 10,00 \\
1991 & 15,0 & 1,2 & 3,44 & 9,10 \\
1992 & 15,8 & 1,3 & 5,33 & 8,33 \\
1993 & 15,6 & 1,4 & $(1,26)$ & 7,69 \\
1994 & 15,8 & 1,4 & 1,28 & 0,00 \\
1995 & 17,2 & 1,6 & 8,86 & 14,28 \\
1996 & 19,0 & 2,0 & 10,46 & 25,00 \\
$1997^{2}$ & 20,3 & 2,3 & 6,84 & 15,00 \\
$1998^{2}$ & 20,1 & 2,4 & $(1,0)$ & 4,35 \\
\hline
\end{tabular}

Fonte: FNP Consultoria \& Comércio, 1999

- Taxa geométrica de crescimento anual

${ }^{2}$ Estimativas

Seguindo a divisão feita pelo IBGE, comparando-se os anos de 1995 e 1998, verifica-se que todas as messoregiões do Estado de Goiás aumentaram, em termos absolutos, a produção de leite, não acontecendo o mesmo com a participação relativa, pois as messoregiões Leste Goiano e Sul Goiano apresentaram diminuição (Tabela 9). Isso pode ser um indício de que a produção de leite do país está migrando para o norte de Goiás, e que estados como Pará e Tocantins serão os próximos a experimentar crescimento na produção, movidos pelo entusiasmo dos produtores e aparecimento de novos compradores, como, por exemplo, a nova fábrica que se instalou no município de Porangatu. 
Tabela 9. Produção de leite das Messoregiões do Estado de Goiás e participação relativa desta produção, 1995 a 1998.

\begin{tabular}{lrrrrrrrr}
\hline \multirow{2}{*}{ Messoregiões } & \multicolumn{8}{c}{ Produção de Leite } \\
\cline { 2 - 9 } & \multicolumn{2}{c}{1995} & \multicolumn{1}{c}{1996} & \multicolumn{1}{c}{1997} & \multicolumn{2}{c}{1998} \\
\cline { 2 - 9 } & (mil litros) & $(\%)$ & (mil litros) & (\%) & (mil litros) & $(\%)$ & (mil litros) & $(\%)$ \\
\hline Noroeste & 105.878 & 7,30 & 149.745 & 7,49 & 154.047 & 8,24 & 161.725 & $\mathbf{8 , 1 7}$ \\
Norte & 82.259 & 5,67 & 98.448 & 4,92 & 99.648 & 5,33 & 115.050 & 5,81 \\
Centro & 368.025 & 25,38 & 539.249 & 26,97 & 571.829 & 30,60 & 591.345 & 29,89 \\
Leste & 110.235 & 7,60 & 199.345 & 9,97 & 117.917 & 6,31 & 124.208 & 6,28 \\
Sul & 783.761 & 54,05 & 1.012 .612 & 50,65 & 925.536 & 49,52 & 986.251 & 49,85 \\
GOIÁS & 1.450 .158 & 100,00 & 1.999 .398 & 100,00 & 1.868 .976 & 100,00 & 1.978 .579 & 100,00 \\
\hline
\end{tabular}

Fonte: SEPLAN-GO/SEPIN, 1995/1996/1997/1998

Embora a participação na produção de leite das messoregiões Norte e Nordeste Goiano vem aumentado, em suas microrregiões, São Miguel do Araguaia, Rio Vermelho, Aragarças, Porangatu e Chapada dos Veadeiros, a relação entre vacas ordenhadas e efetivo bovino é baixa (Tabela 10), o que evidencia ainda, uma menor importância dedicada a este tipo de atividade. Por outro lado, as microrregiões ao sul e centro goiano, realçam a importância da pecuária leiteira, com participações relativas no número de vacas ordenhadas, igual ou superior a $20 \%$ do total do efetivo do rebanho bovino existente. A produtividade obtida em cada microrregião, em termos comparativos às produtividades alcançadas em países como Israel e Estados Unidos é extremamente baixa, vai de 223,81 litros/vaca/ano até 748,89 litros/vaca/ano nas respectivas microrregiões Vão do Paraná no Nordeste Goiano e Meia Ponte no Sul Goiano. 
Tabela 10. Efetivo do rebanho bovino, vacas ordenhadas, produção de leite e produtividade por Microrregião do Estado de Goiás - 1994.

\begin{tabular}{lrrrrr}
\hline Microrregião & $\begin{array}{c}\text { Efetivo } \\
\text { bovino }\end{array}$ & $\begin{array}{c}\text { Vacas } \\
\text { ordenhadas }\end{array}$ & Relação & $\begin{array}{c}\text { Produção } \\
\text { (mil litros) }\end{array}$ & $\begin{array}{c}\text { Produtividade } \\
\text { (litros/vaca/ano) }\end{array}$ \\
\hline S.M.Araguaia & 1.254 .500 & 56.810 & 0,04 & 21.235 & 373,79 \\
Rio Vermelho & 2.185 .250 & 191.500 & 0,09 & 51.662 & 269,77 \\
Aragarças & 680.000 & 69.000 & 0,10 & 31.560 & 457,39 \\
Porangatu & 1.081 .300 & 131.700 & 0,12 & 53.182 & 403,81 \\
C. Veadeiros & 265.400 & 22.630 & 0,08 & 5.585 & 246,80 \\
Ceres & 904.200 & 169.300 & 0,19 & 80.284 & 474,21 \\
Anápolis & 726.402 & 139.672 & 0,19 & 81.195 & 581,33 \\
Iporá & 615.800 & 106.226 & 0,17 & 49.697 & 467,84 \\
Anicuns & 659.090 & 120.990 & 0,18 & 69.845 & 577,28 \\
Goiânia & 565.710 & 119.743 & 0,21 & 86.197 & 719,85 \\
Vão do Paranã & 460.410 & 27.420 & 0,06 & 6.137 & 223,81 \\
E.de Brasília & 1.201 .290 & 227.029 & 0,19 & 101.448 & 446,85 \\
Sudoeste Goiás & 2.784 .000 & 319.930 & 0,11 & 181.578 & 567,55 \\
V.R.dos Bois & 1.081 .270 & 237.580 & 0,22 & 142.109 & 597,15 \\
Meia Ponte & 1.637 .682 & 332.956 & 0,20 & 249.347 & 748,89 \\
Pires do Rio & 436.050 & 88.200 & 0,20 & 61.746 & 700,07 \\
Catalão & 515.210 & 90.060 & 0,17 & 38.729 & 430,03 \\
Quirinópolis & 1.343 .500 & 185.800 & 0,14 & 102.814 & 553,36 \\
Total do Estado & 18.397 .064 & 2.636 .546 & 0,14 & 1.409 .351 & 534,54 \\
\hline
\end{tabular}

Fonte: SEPLAN-GO/SEPIN, 1996

${ }^{1}$ Relação entre o número de vacas ordenhadas e o total do efetivo bovino.

A menor ou maior dedicação à atividade leiteira, corrobora os aspectos das participações anteriormente comentados em relação a evolução desta atividade produtiva no Estado de Goiás.

Num universo de 232 municípios produtores, apenas $14 \%$ do total dos animais, em média, são vacas destinadas à ordenha para produção de leite. Os dez principais municípios produtores de leite no estado de Goiás, em 1994, foram Piracanjuba, Quirinópolis, Jataí, Morrinhos, Rio Verde, Paraúna, Itumbiara, Pontalina, Mineiros e Trindade, concentram $23,7 \%$ da produção leiteira goiana (Tabela 11). As participações relativa da pecuária leiteira no total do efetivo bovino, realça a importância que é dispensada a esta atividade em cada município que chega a $30 \%$ em Trindade, 
$26 \%$ em Piracanjuba e $25 \%$ em Morrinhos. Conjugado a isto, estes municípios apresentam-se como possuidores das melhores produtividades deste tipo de rebanho, atingindo em Piracanjuba a maior média 867,59 litros/vaca/ano, Trindade com 852,01 litros/vaca/ano e Morrinhos em $3^{\circ}$ lugar com 834,40 litros/vaca/ano. Neste grupo Paraúna ostenta a menor média alcançando 540,00 litros/vaca/ano.

Tabela 11. Principais Municípios produtores de leite, efetivo bovino, vacas ordenhadas, produção de leite e produtividade em Goiás, 1994.

\begin{tabular}{lccccc}
\hline Município $^{1}$ & $\begin{array}{c}\text { Efetivo } \\
\text { Bovino } \\
(\mathrm{B})\end{array}$ & $\begin{array}{c}\text { Vacas } \\
\text { Ordenhadas } \\
(\mathrm{V})\end{array}$ & $\begin{array}{c}\text { Relação } \\
\text { (V/B) }\end{array}$ & $\begin{array}{c}\text { Produção } \\
\text { de leite } \\
\text { (mil litros) }\end{array}$ & $\begin{array}{c}\text { Produtividade } \\
\text { (litros/vaca/ano) }\end{array}$ \\
\hline Piracanjuba & 212.450 & 55.110 & 0,26 & 47.813 & 867,59 \\
Quirinópolis & 380.000 & 62.000 & 0,16 & 44.640 & 720,00 \\
Jataí & 420.000 & 57.000 & 0,13 & 41.200 & 722,81 \\
Morrinhos & 189.152 & 47.290 & 0,25 & 39.459 & 834,40 \\
Rio Verde & 505.000 & 53.000 & 0,10 & 38.160 & 720,00 \\
Paraúna & 248.100 & 53.000 & 0,21 & 28.620 & 540,00 \\
Itumbiara & 219.700 & 42.700 & 0,19 & 28.500 & 667,44 \\
Pontalina & 135.000 & 28.000 & 0,21 & 22.932 & 819,00 \\
Mineiros & 290.000 & 40.200 & 0,14 & 22.900 & 569,65 \\
Trindade & 80.300 & 24.090 & 0,30 & 20.525 & 852,01 \\
\hline
\end{tabular}

Fonte: SEPLAN-GO/SEPIN, 1996

${ }^{1}$ Dos dez municipios maiores produtores de leite, 4 estão na microrregião Meia Ponte, 3 na Sudoeste de Goiás, 1 na de Quirinópolis, 1 na de Vale do Rio dos Bois e 1 na de Goiânia. 


\section{REVISÃO DE LITERATURA}

A administração rural divide-se em quatro funções fundamentais: planejamento, organização, direção e controle. O planejamento é uma atividade que consiste na prévia determinação dos objetivos a serem alcançados; Sendo assim, é considerado o ponto de partida do processo administrativo. A organização se preocupa em agrupar e estruturar todos os recursos da empresa, a fim de atingir os objetivos predeterminados. A direção atua sobre os recursos humanos, compreendendo suas reações e comportamentos, com o intuito de assegurar o êxito do planejamento e da organização. A função administrativa de controle devolve as informações ao planejamento, a fim de que o ciclo administrativo tenha continuidade, e verifica se todas as ações estão sendo executadas corretamente, de acordo com o que foi planejado (Souza et al., 1995). Então, a função, controle é de vital importância dentro da empresa, pois permite que os erros sejam sanados em tempo hábil, evitando que se comprometam as demais funções do processo de produção.

Segundo Souza et al. (1995), o controle pode ocorrer: a) em nível estratégico onde se procura avaliar o desempenho global da empresa através de relatórios contábeis, controle de lucros e perdas, e análise sobre o investimento; b) em nível intermediário, onde cada unidade, tal como departamento ou divisão, é avaliada e; c) em nível operacional, onde se cuida do nível mais baixo da empresa, dando a cada tarefa uma visão mais de curto prazo.

Numa abordagem de negócios na administração agropecuária, o produtor deve ter ferramentas para descrever financeiramente a atividade em andamento e evidenciar seu desempenho (Procópio, 1996). Para isso, pode-se criar um sistema de informações. 
Santos \& Marion (1996, p. 15), definem, de forma objetiva e prática, sistema de informações como sendo "as normas e procedimentos que, de forma sistemática, visam proteger os bens patrimoniais, assegurar a exatidão e veracidade de seus registros contábeis e extra contábeis e a manter e aprimorar a política diretiva e estratégica da empresa". Desta forma, as informações podem ser agrupadas segundo sua origem, em internas e externas.

As informações de origem externa são aquelas provenientes de fontes de fora da empresa, geralmente divulgadas através dos meios de comunicação, como jornais, revistas e televisão, ou as que a empresa obtém através de outras fontes, encomendando pesquisas ou efetuando levantamento junto às associações de classe, por exemplo (Silva, 1995).

No grupo das informações de origem interna, temos as que não decorrem dos registros contábeis, como a participação no mercado que atua por exemplo, e as que são de natureza contábil e que normalmente são expressas em valores monetários.

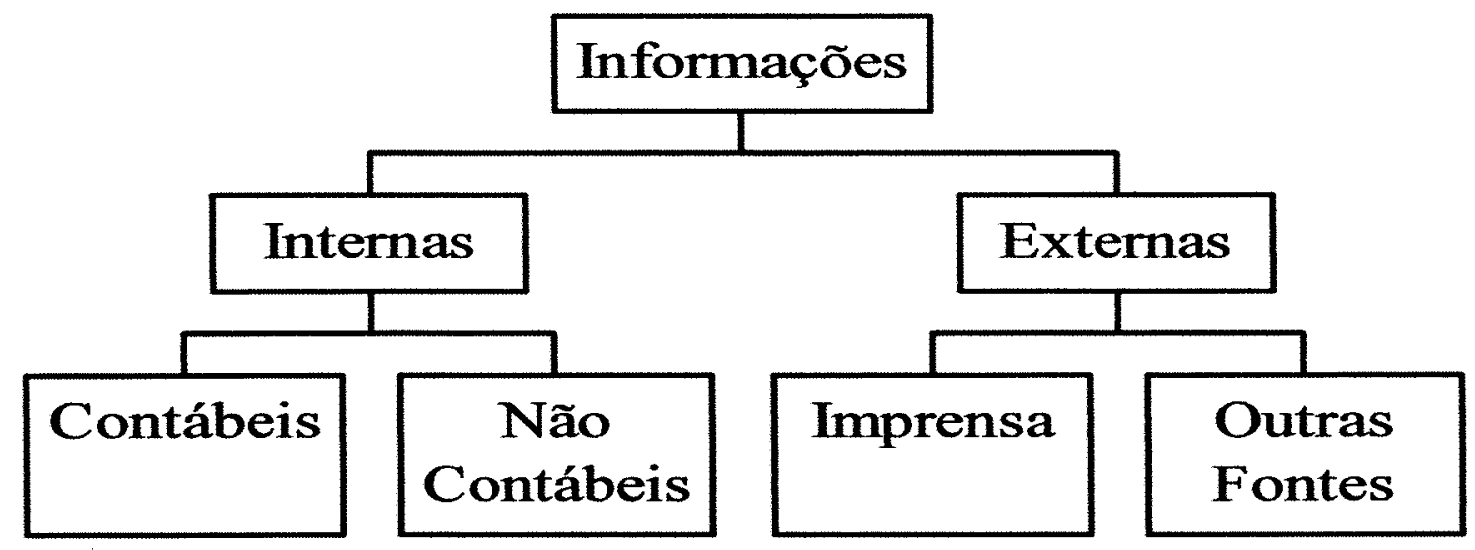

Figura 1 - Organograma das informações segundo suas origens.

Fonte: Silva (1995)

As informações de natureza contábil são registradas por meio do uso da contabilidade. A utilização da contabilidade é importante pois permite, dentre outras, analisar o desempenho financeiro e a força do empreendimento, justificar a necessidade 
de empréstimos e financiamentos, analisar a eficiência da produção, avaliar a capacidade para pagamento dos compromissos e prover dados para avaliar o investimento.

A organização de um sistema de informações contábeis compreende o planejamento das tarefas pertinentes à área, envolvendo o método de escrituração, os planos de registros, normas e rotinas de trabalho.

Não se pode esquecer porém, que o sistema de informações internas contábeis não demonstram o perfil do administrador, as potencialidades e ameaças do mercado, a vulnerabilidade face as flutuações econômicas ou as decisões governamentais, o nível tecnológico da empresa, os impactos ambientais e a satisfação de clientes e de empregados.

Mesmo assim, um sistema de informação interno contábil muito utilizado é o Sistema de Custos, que segundo Santos \& Marion (1996, p. 35), “é um conjunto de procedimentos administrativos que registra, de forma sistemática e contínua, a efetiva remuneração dos fatores de produção empregados nos serviços rurais".

Como a contabilidade convencional apoia-se no Princípio de Custo Histórico, ou seja, no valor de aquisição dos bens que integram o patrimônio para avaliar o nível de riqueza acumulado pelas unidades produtivas em determinada data, e não no valor de mercado, o que foi utilizado como critério na avaliação dos inventários desta pesquisa, nesta dissertação tratar-se-á especificamente do custo econômico, também denominado por alguns estudiosos como custo gerencial. $\mathrm{O}$ que doravante define o custo é a compensação aos donos dos fatores de produção utilizados para produzir um bem ou serviço, isto porque existem itens que compõem o custo, mas que na verdade não ocorre o pagamento formal ao dono do fator de produção.

Segundo Santos \& Marion (1996), o custo econômico pode ser classificado, quanto à sua variação quantitativa de acordo com o volume de produção em:

a) Custos Variáveis: são aqueles que variam conforme se altere a quantidade produzida, como exemplo tem-se o custo com alimentação do rebanho.

b) Custos Fixos: são aqueles que não variam, em termos físicos e de valor, conforme alterações na quantidade produzida considerando-se um intervalo de 
tempo relevante. Geralmente são oriundos da posse de ativos permanentes e da capacidade ou estado de prontidão para produzir, como exemplo tem-se o pagamento do salário do vaqueiro.

Vários pesquisadores, em diferentes regiões, estudam custo de produção. Os princípios conceituais considerados são os mesmos, mas há particularidades na metodologia e nas fórmulas utilizadas no cálculo em si, de acordo com o objeto do estudo e da realidade da região estudada.

As maiores diferenças encontram-se na metodologia considerada, especificamente, nos itens que serão imputados no custo fixo, a exemplos da depreciação, do seguro sobre o patrimônio, da compensação sobre a mão-de-obra familiar, do empresário, da terra e dos juros sobre o capital investido. As divergências vão além da terminologia adotada e passam a ser de cunho técnico, pois abrangem quais os itens a serem considerados no custo e qual a fórmula que deveria ser utilizada para seu cálculo. Diferenças importantíssimas pois estão ligadas ao valor numérico do resultado final do custo médio.

A exemplo de tais diferenças cita-se Toledo (2001), que ao estudar uma propriedade em Ipameri-GO, utilizou na composição do custo fixo a remuneração sobre a mão-de-obra familiar, depreciação de todas as benfeitorias, máquinas e equipamentos que não estiverem ligados à produção de alimentos, depreciação de todos animais, exceto os de engorda, compensações sobre o capital investido e sobre o capital de giro, este último classificado como custo variável. Mas não utiliza a compensação pelo uso da terra e a remuneração do empresário.

No caso da remuneração sobre o capital investido, Toledo (2001), utilizou a seguinte fórmula:

$$
\mathrm{CCI}=\frac{(V U-I d)}{V U} \times V N \times \text { TJuros }
$$

onde: $\mathbf{C C I}=$ Compensação sobre o Capital Investido

VU = Vida Útil do bem considerado, a partir do bem novo, em anos

Id = Idade do bem considerado, no momento do cálculo, em anos

$\mathrm{VN}=$ Valor Novo do bem considerado 
TJuros $=$ Taxa de Juros, neste caso $12 \%$ aa

Já Noronha et al. (1999) e Canziani (1999), calculam a remuneração sobre o capital investido, multiplicando o valor médio do capital inicial e final pela taxa de juros. Mas, embora utilize a mesma fórmula, diferem nos itens considerados para calcular tal compensação. É importante salientar que na composição do valor médio, usa-se o valor atual e não o valor novo do item em questão. Ao se utilizar o valor médio, nos primeiros anos o valor calculado da remuneração será menor que o valor que realmente deveria ser imputado, mas nos últimos períodos o valor será maior, sendo assim ocorrerá uma compensação.

Quando se imputa no custo de produção o valor do seguro sobre o patrimônio, Noronha et al. (2001) e Canziani (1999), aplicam uma taxa de seguro sobre o valor médio do patrimônio, desta forma, assim como no caso da remuneração sobre o capital investido, esse valor será menor nos primeiros anos e maior nos últimos.

Após solucionar estas questões metodológicas de sobre os itens a serem considerados no custo fixo e como calculá-los, Noronha el al. (2001), alertam para a diferença em se calcular o custo da atividade leiteira e o custo do leite. Isso devido à impossibilidade de se produzir somente o leite, pois do mesmo processo obtém-se os animais descartados e o esterco, ou seja, o leite é um joint product.

Segundo Figueiredo (1997, p. 383), "entende-se por centro de custo de uma empresa, qualquer unidade de agregação de custo realizando uma atividade ou um conjunto de atividades que detém certas similaridades", ou seja, a divisão da empresa rural em atividades ou unidades de produção, onde é possível distinguir com razoável precisão, os produtos ou serviços gerados e os períodos de tempo necessários para produzi-los.

Já as unidades de custo se fazem necessárias quando se deseja calcular os valores dos recursos usados no processo de geração desses produtos, como é o exemplo da silagem de milho, ou para diferenciar o produto final em leite, bezerro, carne e outras, Noronha el al. (2001). Desta forma, para diferenciar o custo da atividade leiteira do 
custo do leite, seria necessário mas não suficiente ${ }^{2}$, por exemplo, criar o centro de custo atividade leiteira e as unidades de custo produção de leite, recria de bezerras, criação de tourinhos e outras.

Quanto à fórmula utilizada para calcular o custo econômico médio do leite, assim como os itens que irão compor o custo, dependerão de qual o objetivo que se destina o cálculo. Noronha el al. (1990), verificou a possibilidade de uso de quatro alternativas diferentes, que serão apresentadas a seguir, bem como distorções provocadas pela alteração das variáveis que as definem.

Primeira alternativa:

A primeira fórmula, consiste em dividir os custos totais da atividade pela quantidade total de leite produzido.

$$
C M e_{1}=\frac{C T A}{Q L}
$$

onde: $\mathrm{CMe}_{1}=$ custo médio do litro de leite, calculado pela alternativa 1, em R\$

CTA = custo total da atividade leiteira, em R\$

$\mathrm{QL}=$ quantidade de leite produzida, em litros

Esta alternativa de cálculo superestima o custo médio do litro de leite pois não considera a renda proveniente dos outros produtos da atividade leiteira, venda de animais e esterco, por exemplo, mas considera os custos provenientes do processo produtivo desses produtos, ou seja, dessas unidades de custo.

\section{Segunda alternativa:}

Consiste em subtrair dos custos totais da atividade a renda proveniente da venda dos outros produtos que integram a atividade leiteira.

$$
C M e_{2}=\frac{(C T A-O R A L)}{Q L}
$$

\footnotetext{
${ }^{2}$ Mesmo neste caso a unidade de custo "produção de leite" estaria produzindo, além do leite, as vacas descartadas e o esterco desta unidade. Permanece, portanto, a produção conjunta nesta unidade.
} 
onde: $\mathrm{CMe}_{2}=$ custo médio do litro de leite, calculado pela alternativa 2, em R\$

CTA = custo total da atividade leiteira, em R\$

ORAL = outras rendas da atividade leiteira: venda de esterco, animais e outros produtos da atividade leiteira, em R\$

$\mathrm{QL}=$ quantidade de leite produzida, em litros

Esta alternativa de cálculo, segundo Noronha et al. (1990), talvez seja a fórmula mais utilizada. Um dos defeitos desta fórmula, é partir da premissa que o valor das outras rendas da atividade leiteira tem o mesmo valor do custo, sendo assim, os demais produtos não podem dar lucro, o que é uma conclusão errônea, uma vez que a venda de animais é uma das alternativas responsáveis pela continuidade da produção de leite.

Outro questionamento a essa fórmula é qual seria o custo médio quando o valor das outras rendas da atividade leiteira for maior que o valor do custo total da atividade. Matematicamente seria negativo, fica então difícil de imaginar uma atividade com custo negativo de produção.

Deve-se alertar também, para a situação onde se utiliza essa fórmula para negociar preço com o setor de laticínios, isto porque os preços dos outros produtos da atividade leiteira interferem na fórmula; por exemplo, em períodos que o preço dos animais estão altos, o custo médio diminui mesmo que nada aconteça aos custos dos fatores de produção. Noronha et al. (1990), afirma que este efeito acentua-se mais ainda nas propriedades onde os rebanhos possuem animais de menor grau de sangue leiteiro, pois nestes casos a venda de animais é um fator mais importante na composição da renda do produtor.

\section{Terceira alternativa:}

Esta alternativa consiste em somar ao total de leite produzido, a renda proveniente da venda dos outros produtos que integram a atividade leiteira transformada em leite. 


$$
C M e_{3}=\frac{C T A}{\left(Q L+\frac{O R A L}{P L}\right)}
$$

onde: $\mathrm{CMe}_{3}=$ custo médio do litro de leite, calculado pela alternativa 3 , em R\$

$\mathrm{CTA}=$ custo total da atividade leiteira, em RS

ORAL = outras rendas da atividade leiteira, venda de esterco, animais e outros produtos da atividade leiteira, em R\$

$\mathrm{PL}=$ preço do litro de leite recebido pelo produtor, em $\mathrm{R} \$$

$\mathrm{QL}=$ quantidade de leite produzida, em litros

Nesta forma de cálculo, além da variável preço dos outros produtos da atividade leiteira interferirem na fórmula, Noronha et al. (1990) alerta para a influência que o preço do leite também exerce sobre o resultado, pois ao se transformar o valor da venda dos outros produtos em equivalente leite, quanto mais baixo o preço do leite, maior será a quantidade de leite que deve ser somada ao que se produziu. Desta forma, caso diminua apenas o preço do leite, mantendo-se as demais variáveis constantes, matematicamente irá obter um custo médio menor, induzindo a conclusão de que quanto menor o preço do leite, menor será o custo, o que nem sempre é verdade.

\section{Quarta alternativa:}

Segundo Noronha et al. (1990), esta alternativa consiste no reconhecimento que a renda do produtor depende de todos os produtos da atividade leiteira e não apenas do leite. Tem como objetivo maximizar o lucro da atividade, não importando como é gerada a renda total. Sendo assim, o que se procede é uma "correção" da quantidade produzida de leite, pela participação da renda dos outros produtos na renda total da atividade.

$$
\mathrm{CMe}_{4}=\frac{C T A}{Q L} \times \frac{R T A}{(R T A+O R A L)}
$$

onde: $\mathrm{CMe}_{4}=$ custo médio do litro de leite, calculado pela alternativa 4, em R\$

CTA = custo total da atividade leiteira, em R\$

$\mathrm{QL}=$ quantidade de leite produzida, em litros 
$\mathrm{RTA}=$ renda total da atividade leiteira, em $\mathrm{R} \$$

$\mathrm{ORAL}=$ outras rendas da atividade leiteira, venda de esterco, animais e outros produtos da atividade leiteira, em R\$

Embora esta fórmula também apresente o inconveniente de deixar o custo médio dependente dos preços dos produtos, apresenta o ponto positivo de inserir na ponderação não só o preço do leite, mas também sua quantidade, permitindo que o viés torna-se menor à medida que a atividade seja mais especializada na produção de leite, ou sejạ, à medida que diminui a proporção de ORAL na RTA.

Todas as alternativas para calcular o custo médio apresentadas acima, podem provocar algum viés no resultado, a questão é: qual delas interferiria menos nos resultados? Segundo Noronha et al. (1990), para negociação de preço dificilmente se aceitaria a primeira alternativa, restaria as outras três. Ainda segundo Noronha et al. (1990, p. 13), “entre estas, sob o critério de escolher-se aquela cujo resultado do cálculo for menos afetado pelas variações dos preços dos produtos, a terceira e a quarta fórmula seriam iguais se os preços dos produtos variassem na mesma proporção, o que é pouco provável. Desta forma, a quarta fórmula resultaria sempre em menores variações nos resultados".

É importante lembrar que, mesmo quando se adota um sistema de controle dividindo-se a empresa em atividades e estas em unidades de custo, seria mais coerente calcular o custo da atividade leiteira e a partir daí, calcular o custo do leite por meio de alguma ponderação. Gomes (1999), propõe como solução, calcular o custo médio da atividade leiteira pela primeira alternativa de cálculo e a partir daí, ponderar, através da distribuição dos custos da atividade na mesma proporção da renda bruta dos diferentes produtos, o custo médio do leite. Noronha et al. (2001), estudando 30 propriedades, verificou que tal procedimento apresenta duas limitações: a primeira implica em assumir que o valor do leite e o dos outros produtos da atividade guardam uma proporção fixa durante o período de tempo, o que é pouco provável de acontecer, e a segunda é que subestima o custo médio, neste caso específico de 5,5 a $10 \%$, em relação ao valor encontrado quando se calcula o custo médio através da quarta alternativa. 
Um estudo da Faemg (1996), realizado em 996 propriedades do Estado de Minas Gerais no ano de 1995, considerando a mão-de-obra familiar e a depreciação no custo fixo, calculou para a amostra o custo médio do leite, por meio da primeira alternativa, de $\mathrm{R} \$ 0,30 /$ litro de leite. A mesma pesquisa considerou como pequeno produtor, aquele com produção diária de até 50 litros de leite, médio de 51 a 250 litros de leite/dia e como grande produtor, quem produzia acima de 250 litros de leite diariamente, obteve para essa estratificação custo de $R \$ 0,32$, R\$ 0,28 e R\$ 0,25 por litro, respectivamente.

Gomes (1999), trabalhando com uma propriedade no ano de 1998, em Bom Despacho-MG, calculou, também utilizando a primeira alternativa de cálculo, o custo médio da atividade leiteira em $R \$ 0,28$ /litro de leite, sendo o mesmo incompatível com o preço pago ao produtor rural na época de $\mathrm{R} \$ 0,26 /$ litro de leite. Mas, ao proceder a ponderação do custo médio do leite, por meio da distribuição dos custos da atividade na mesma proporção da renda bruta, chegou a um custo médio do leite de $R \$ 0,22 /$ litro, sendo tal resultado compatível com o preço médio recebido.

Fellet \& Galan (2000), analisando 24 propriedades em 1998, $10 \mathrm{em}$ Ituiutaba-MG, 8 em Araçatuba-SP e 6 em Porto Fereira-SP, por meio da quarta alternativa para calcular o custo médio, chegaram aos valores de $R \$ 0,208,0,266$ e 0,392 respectivamente por município, e para a amostra, custo de $R \$ 0,279 /$ litro de leite. Na composição dos custos fixos, os itens de mão-de-obra familiar e depreciação foram considerados, mas não consideraram seguro, compensação sobre o capital médio, sobre o capital de giro, do empresário e pelo uso da terra.

A mesma pesquisa verificou que o preço médio recebido pelo produtor foi de $R \$$ 0,249/litro em Ituiutaba, $R \$$ 0,261/litro em Araçatuba e R\$ 0,283/litro nas propriedades estudadas em Porto Ferreira. Comparando o preço médio recebido pelo produtor de cada município com o respectivo custo médio deste município, verifica-se situação desfavorável para os produtores dos municípios de Araçatuba e Porto Ferreira e favorável para os produtores do município de Ituiutaba. Mas, os autores ressaltam como limitação deste trabalho à metodologia adotada para coleta dos dados, feita por meio de 
aplicação de questionário e recuperação de notas em uma visita apenas, o que pode subestimar o custo de produção.

Já Toledo (2000), utilizando a segunda alternativa para cálculo do custo médio de produção do leite, chegou a R\$ 0,4033/litro, pesquisando uma propriedade no município de Ipameri-GO. O autor ressalta a importância da participação do item alimentação na composição do custo de produção, cerca de $50 \%$. È importante esclarecer que na metodologia, considerou-se na alimentação, não só os gastos com a compra de concentrado, mas também o que se gastou de hora-máquina na produção do volumoso, bem como o valor da depreciação de todo maquinário envolvido nesta produção.

A análise de custo de produção, embora contribua para o gerenciamento da propriedade rural, subsidiando o empresário em sua decisão, apresenta a deficiência de não abranger de forma detalhada, toda a estrutura da empresa. Para solucionar esse problema, pode-se utilizar o Balanço Patrimonial, outro exemplo de sistema de informação contábil, por meio do qual se pode conhecer a situação patrimonialfinanceira da empresa em um determinado momento (Mattos, 1999).

$O$ balanço retrata a posição patrimonial da empresa em um determinado momento, composta por bens, direitos e obrigações, e é composto por ativo e passivo. $\mathrm{O}$ ativo mostra onde a empresa aplicou seus recursos, ou seja, os bens e direitos que ela possui, e o passivo de onde vieram os recursos, isto é, se são provenientes de terceiros ou do proprietário da empresa.

Os demonstrativos contábeis são bastante úteis para se determinar o valor de mercado das empresas, mas eles não o retratam com fidelidade, pois a tarefa de estimar o valor de mercado de um bem é subjetiva e complexa. Por isso Leite (1988), afirma que o último documento a ser consultado para avaliar o preço a ser cobrado na venda de uma empresa em operação seja o seu balanço patrimonial.

A Lei $\mathrm{n}^{\circ} 6.404 / 76$, mais precisamente os artigos 178 a 182, regulamentam a utilização do Balanço Patrimonial. O artigo 178 trata da classificação das contas segundo os elementos do patrimônio que registram, mas é no parágrafo 1 que divide o ativo em contas conforme o grau de liquidez dos elementos nelas registrados, assim tem- 
se ativo circulante, ativo realizável à longo prazo e ativo permanente, dividido em investimentos, ativo imobilizado e ativo diferido (Silva, 1995).

Utilizando-se os dados do Balanço Patrimonial, pode-se calcular indicadores que permitem fazer uma análise financeira atividade desenvolvida.

Quando se utilizam indicadores para avaliar a situação econômica de uma empresa, o balanço patrimonial, por si só, não fornece todos os dados necessários para o cálculo destes indicadores, se faz necessário utilizar Contas de Resultado. Essas contas são empregadas para o registro e a acumulação de receitas e despesas de determinado período de tempo e cujos saldos integram a Demonstração de Resultados referentes a este determinado período de tempo (Leite, 1988).

Resumindo, segundo Silva (1995, p.95), “o balanço patrimonial é utilizado para representar a posição da empresa em um determinado momento, já a demonstração do resultado agrupa valores relativos das receitas, custos dos produtos $e$ despesas referentes a um período de tempo, possibilitando determinar o lucro ou prejuizo obtido pela empresa deste período".

\subsection{Análise Financeira}

A análise visa avaliar a saúde financeira e a rentabilidade obtida pela empresa em um dado período. Pode-se utilizar os seguintes indicadores financeiros e de rentabilidade ${ }^{3}$.

\subsubsection{Endividamento (E)}

O endividamento é um indicador financeiro muito usado que expressa a relação entre capital de terceiros ou passivo exigível e o ativo total. É usado para verificar quanto do ativo da empresa foi financiado por recursos de terceiros.

\footnotetext{
${ }^{3}$ A descrição dos indicadores foi baseada em: Mattos, 1999; Pfaltzgraff, 1985; Ross et al., 1995; Walter \& Braga, 1981.
} 


$$
E=\frac{P E}{A T}
$$

onde: $\mathrm{PE}=$ Passivo Exigível (soma do passivo circulante e do exigível a longo prazo)

$$
\text { AT }=\text { Ativo Total }
$$

É usado para verificar quanto do ativo da empresa foi financiado por recursos de terceiros. Segundo Mattos (1999), quanto mais alto for esse índice, mais vulnerável é a empresa.

Quanto menor o endividamento, menor é a participação de recursos de terceiros na composição do ativo da empresa; quanto maior, maior é a participação de recursos de terceiros compondo o ativo da empresa.

Se uma empresa operar com quase completa autonomia financeira, o seu endividamento deverá estar próximo de zero. Assim, geralmente, para que uma empresa opere com boa estabilidade financeira, seu endividamento deverá estar próximo de zero e não de um.

Se o endividamento for igual a 1 (um), expressará, neste momento, um ativo total financiado exclusivamente por recursos derivados de terceiros, sendo nulo patrimônio líquido do proprietário.

Segundo Marion (1998), em geral, as empresas que vão à falência apresentam em seu ativo, uma alta participação de capital de terceiros compondo seu ativo.

Mattos (1999) alerta para a importância de se conhecer as razões que levaram a empresa a endividar-se, e não somente o valor do índice. Isso porque, segundo a autora, se ocorreu aumento do endividamento provocado pela aplicação em ativos que irão gerar lucros futuros, é uma situação desejável, mas se é para pagar antigas obrigações, tal situação é indesejável e arriscada.

Partindo de um estudo realizado em cooperativa de produtores rurais de assentamento de reforma agrária e utilizando a fórmula acima, verificou-se que 0,8434 do ativo total desta cooperativa é financiado por recursos derivados de terceiros, o que 
representaria um percentual elevado, demonstrando baixa autonomia financeira de tal empresa Assumpção \& Veiga (2000).

\subsubsection{Retorno do Capital Total (RCT)}

O Retorno do Capital Total é um indicador de rentabilidade calculado a partir da razão entre Lucro Líquido do Exercício mais Despesa Financeira e Valor Médio do Total do Ativo.

$$
R C T=\frac{(L L+D F)}{\frac{(T A I+T A F)}{2}}
$$

onde: $\mathrm{LL}=$ Lucro Líquido do Exercício

$\mathrm{DF}=$ Despesa Financeira

TAI = Valor Total do Ativo da empresa no início do período contábil

$\mathrm{TAF}=$ Valor Total do Ativo da empresa no final do período contábil

É através deste indicador, "que a empresa conhece o quanto suas aplicações, representadas pelo valor de seu ativo médio no periodo, lhe renderam, independentemente de como esses ativos foram financiados" (Mattos, 1999, p.56). Ainda segundo a autora, esse seria o motivo pelo qual no numerador da fórmula, utilizase o somatório entre o lucro líquido obtido na demonstração do resultado do exercício, $\mathrm{e}$ as despesas financeiras, ou seja, não se deduz juros, dividendos ou quaisquer outros custos devidos pela empresa aos financiadores de capital. Já as empresas não rurais, utilizam no numerador, o valor do lucro líquido proveniente da demonstração de resultado do exercício, ou seja, deduzido das despesas financeiras, sendo assim, é aconselhável se evitar comparações entre empresas rurais e urbanas.

Ao decompor o retorno do capital total em Margem Líquida sobre Vendas e Giro do Ativo, tem-se o indicador de análise de rentabilidade pelo Método DuPont. 
Segundo Marion (1998, p.508), "duas propriedades podem apresentar o mesmo retorno líquido sobre o ativo total, porém com margem líquida sobre vendas $e$ giro do ativo bastante diferentes".

$$
R C T=M L \quad x \quad G A
$$

onde: $\mathrm{ML}=$ Margem Líquida sobre Vendas;

$\mathrm{GA}=$ Giro do Ativo

A margem líquida sobre vendas mede a eficiência financeira da empresa em termos de retorno por unidade monetária de vendas líquidas no período. Especificamente na atividade leiteira, considera-se que a receita do produtor é proveniente da venda de leite e de subprodutos. Noronha et al. (1990), salienta que o que deve ser utilizado é a renda operacional líquida ${ }^{4}$ no lugar das vendas líquidas. Desta forma, o que se calculará será uma "proxy" da margem líquida, do giro do ativo e do retorno do capital total.

$$
M L=\frac{(L L+D F)}{R O L}
$$

onde: $\mathrm{ROL}=$ Renda Operacional Líquida

O giro do ativo permite medir a eficiência de utilização do ativo, ou seja, a produtividade do ativo. Esse indicador visa mostrar a velocidade com que o ativo se transforma em volume de vendas.

$$
G A=\frac{R O L}{\frac{(T A I+T A F)}{2}}
$$

onde: $\mathrm{TAI}=$ Valor Total do Ativo da empresa no início do período contábil

$\mathrm{TAF}=$ Valor Total do Ativo da empresa no final do período contábil

Logo:

$$
R C T=\frac{(L L+D F)}{R O L} \times \frac{R O L}{\frac{(T A I+T A F)}{2}}
$$

\footnotetext{
${ }^{4} \mathrm{Na}$ atividade leiteira, Renda Operacional Líquida (ROL) é a soma dos valores provenientes da produção de leite in natura e de subprodutos da atividade vendidos, consumidos ou utilizados para pagamento (Hoffmann et al., 1984).
} 
Fellet \& Galan (2000), analisando 24 propriedades em 1998, $10 \mathrm{em}$ Ituiutaba-MG, 8 em Araçatuba-SP e 6 em Porto Fereira-SP, verificaram margem líquida sobre vendas de $28,9 \%, 29,9 \%$ e (-30\%); giro do ativo de $0,164,0,178$ e 0,134 e retorno do capital de $10,3 \%, 10 \%$ e $(-8,8 \%)$ respectivamente para tais municípios. Para a amostra, a margem foi de $17,5 \%$, o giro de 0,165 e o retorno de $5,9 \%$.

Tais resultados mostram que os produtores da bacia de Porto Ferreira encontravam-se na época em situação mais crítica quando comparado aos resultados dos outros dois municípios pesquisados Fellet \& Galan (2000). Os mesmos autores, presenciaram nas propriedades estudadas, um maior nível de investimento em Porto Ferreira e concluem que esse nível é superdimensionado para a produção apresentada.

Um estudo realizado em quatro cooperativas de assentamentos rurais, verificou como resultado médio, $0,51 \%$ de retorno sobre o ativo, decomposto em 0,01 de giro do ativo e 1,45\% de margem de lucro sobre o ativo (Assumpção \& Veiga, 2000). Cabe ressaltar que os autores consideram o lucro líquido, ao invés da renda operacional líquida, na determinação do giro do ativo, e as vendas, no lugar da renda operacional líquida, para determinar a margem, calculando assim a margem de lucro sobre o ativo.

Existem três alternativas que podem ser utilizadas para aumentar o retorno do capital total quando o somatório do lucro líquido com a despesa financeira for positivo. A alternativa mais viável é aumentar a margem líquida e aumentar o giro do ativo, embora também se pode utilizar duas outras alternativas; aumento da margem líquida e diminuição do giro do ativo ou diminuição da margem líquida e aumento do giro do ativo, mas dependerá da magnitude das modificações, ou seja, o resultado final depende do quanto se aumenta a margem e diminui-se o giro; ou quanto se reduz a margem e aumenta-se o giro.

Analisando propriedades rurais, segundo o grau de tecnologia adotada, Jank (1996) simulou qual o sistema de produção que melhor retorno apresentaria, concluindo que o sistema intensivo é que resultaria em um melhor retorno do capital investido, pois o mesmo apresentaria retorno de $13,6 \%$ contra $10,5 \%$ no sistema alternativo com alta tecnologia, $5,4 \%$ no alternativo com baixa tecnologia e $3,8 \%$ no sistema extensivo de produção de leite. 
Essa simulação foi feita considerando quatro níveis de tecnologia adotada, definido pelo autor da seguinte forma: a) sistema extensivo como aquele que utiliza gado mestiço adaptado às condições tropicais, presença de instalações baratas e rudimentares, utilização de mão-de-obra desqualificada, ordenha manual, ausência de resfriador, alimentação dos animais somente a pasto e com baixa lotação de pastagem; b) sistema alternativo, diferenciado em baixa ou alta tecnologia conforme o tipo de animais, qualificação de mão-de-obra e investimentos em máquinas e instalações, mas ambos definịdos pela presença de pastejo rotativo com alta lotação durante o verão e fornecimento de suplemento no cocho e; c) sistema intensivo é definido pela utilização de animais puros, confinamento total, emprego de mão-de-obra qualificada, instalações caras, ordenha mecânica e resfriador de leite (Jank, 1996).

Geralmente, empresas que requerem investimento muito alto, possuem alta margem líquida sobre venda e giro do ativo baixo; e empresas que requerem investimento baixo, possuem margem líquida baixa obrigando-as a ter giro do ativo alto para conseguir retorno positivo sobre o capital total. 


\section{METODOLOGIA}

Segundo Bachman \& Christensen (1956), existem vários critérios que podem ser utilizados para definir o tamanho da unidade de produção. O mais usado é a área da propriedade, geralmente definida em hectares, embora alguns pesquisadores também utilizem-se do valor da produção, de onde pode-se derivar o critério baseado no volume de produção. Portanto, os pesquisadores não utilizam um único critério para definir o tamanho da unidade de produção, e não existe um critério validado para se definir os limites dos estrados, existe sim o uso do bom senso e da experiência do pesquisador na definição de critérios e de limites.

Sendo assim, a metodologia foi definida a partir do projeto "Análise da Rentabilidade da Atividade Leiteira no Estado de Goiás - Projeto Leite" ${ }^{5 "}$. Neste projeto, a amostra foi intencional, utilizou-se o volume da produção como critério para estratificação da amostra, não se adotou nenhum critério estatístico para definir os limites dos estratos, mas utilizou-se da experiência das instituições representativas para definir os municípios participantes e o número de propriedades por estrato. A amostra contemplou os municípios expressivos na produção leiteira e foram escolhidos pela Federação de Agricultura do Estado de Goiás - FAEG. A seleção das 53 propriedades rurais ficou sob responsabilidade dos Sindicatos Rurais ligados a FAEG, divididas segundo o nível de produção diária de leite $\mathrm{em}^{6}$ : pequenos produtores - até 200 litros; médios - de 201 até 500 litros e grandes produtores - acima de 500 litros. Para compor

\footnotetext{
${ }^{5}$ NORONHA, J.F.; NUNES, C.L. de M.; GERALDINE, D.G.; SILVA JUNIOR, R.P. Análise da rentabilidade da atividade leiteira no Estado de Goiás. 1.ed. Goiânia: UFG, 2001. 106p.

${ }^{6}$ Os consultores da FAEG alegam que esta estratificação é fundamentada na justificativa econômica de que considerando o preço dos insumos e o preço pago por litro de leite ao produtor, o mínimo de produção diária de leite em Goiás para se começar a atividade seria de 200 litros.
} 
as 53 propriedades, o critério utilizado foi que a atividade leiteira correspondesse a pelo menos $70 \%$ da renda bruta anual da propriedade.

Os dados foram obtidos em dois momentos. Primeiro, após definir as empresas rurais que participariam da amostra, foi feito um inventário de cada propriedade (Anexo 1) em outubro de 1997. Neste inventário, fez-se uma relação dos bens da propriedade rural, através de entrevista com o produtor. Assim, levantou-se o valor de mercado e a vida útil restante de cada item do ativo (máquinas, implementos, construções, benfeitorias e equipamentos etc.) na data da visita. Neste momento avaliou-se, também, o valor de mercado do rebanho e o uso atual da terra.

Os dados do inventário, uma vez organizados, analisados e criticados, com a participação do produtor, sofreram ajustes e correções de erros de avaliação ou de processamento.

Em um segundo momento, foi organizado também um sistema de coleta mensal de gastos, receitas e investimentos através de Diário (Anexo 2) e Formulário de Controle de Rebanho (Anexo 3) e um sistema de armazenamento de dados, obedecendo um plano de centro de custos (Anexo 4) e um plano de contas (Anexo 5) únicos, previamente definidos, a partir dos quais se processaram os cálculos dos custos, das despesas e das receitas da atividade leiteira. A coleta e o armazenamento dos dados seguiram os mesmos critérios para todos os produtores.

A amostra adotada nesta dissertação foi composta por apenas 20 propriedades rurais, que trabalham exclusivamente com a atividade leiteira, das 53 propriedades contempladas pelo Projeto Leite, distribuídas em três mesorregiões leiteiras do Estado de Goiás, conforme a classificação do IBGE (Quadro 1). Vale ressaltar que as análises apresentadas nos resultados, não são representativas para o estado, por se tratar de um pequeno número de propriedades e não se adotou um critério estatístico na distribuição desta amostra, embora tenha utilizado a experiência dos consultores da FAEG. 


\begin{tabular}{|c|c|c|c|c|c|c|}
\hline \multirow[b]{2}{*}{ Mesorregióes } & \multirow[b]{2}{*}{ Microrregiōes } & \multirow[b]{2}{*}{ Municípios } & \multicolumn{3}{|c|}{ Estratificação } & \multirow[b]{2}{*}{ TOTAL } \\
\hline & & & $\begin{array}{l}\text { Pequenos } \\
\text { (ate } 2001)\end{array}$ & $\begin{array}{l}\text { medros } \\
(16200 \\
5001) \\
950\end{array}$ & $\begin{array}{l}\text { Srandes } \\
\text { (mais de } \\
5001)\end{array}$ & \\
\hline \multirow{3}{*}{$\begin{array}{l}\text { Centro } \\
\text { Goiano }\end{array}$} & Anápolis & Jaraguá & & 1 & & 1 \\
\hline & Ceres & Rubiataba & 2 & & & 2 \\
\hline & Goiânia & $\begin{array}{l}\text { Leopoldo } \\
\text { de Bulhões }\end{array}$ & 1 & & & 1 \\
\hline Leste Goiano & Entorno Brasília & Luziânia & & & 1 & 1 \\
\hline \multirow{6}{*}{ Sul Goiano } & \multirow{2}{*}{ Meia-Ponte } & Morrinhos & 1 & 1 & & 2 \\
\hline & & Piracanjuba & 1 & & 2 & 3 \\
\hline & Pires do Rio & Orizona & 2 & & & 2 \\
\hline & \multirow{3}{*}{$\begin{array}{l}\text { Sudoeste de } \\
\text { Goiás }\end{array}$} & Jataí & & 2 & 1 & 3 \\
\hline & & Mineiros & 1 & 1 & 2 & 4 \\
\hline & & Rio Verde & & 1 & & 1 \\
\hline \multicolumn{3}{|c|}{ TOTAL } & 8 & 6 & 6 & 20 \\
\hline
\end{tabular}

Quadro 1 - Distribuição da amostra segundo a mesorregião, conforme a estratificação.

Fonte: Organizado pelo autor.

Foram feitos os balanços patrimoniais (Quadro 2) anuais, nos meses de outubro de 1997, setembro de 1998 e setembro de 1999, para cada empresa. Ao compor o balanço patrimonial é claro que, por se tratar de empresas do ramo agropecuário e não possuírem controle contábil detalhado, foi necessário fazer algumas adaptações, mas considerando os critérios contábeis de classificação das contas do balanço. Desta forma não se obteve o balanço patrimonial completo, conforme os rigores contábeis exigidos, mas sim uma aproximação do balanço patrimonial. Portanto, os indicadores doravante calculados, também não exibem os valores fieis muitas vezes calculados para as empresas, mas valores aproximados ao verdadeiro. 


\begin{tabular}{|c|l|}
\hline \multicolumn{1}{|c|}{ ATIVO } & \multicolumn{1}{|c|}{ PASSIVO } \\
\hline Circulante & Circulante \\
\hline Crédito de Curto Prazo a Receber & $>$ Dívidas com Fornecedores \\
\hline$\bullet$ Contas a Receber de Clientes & $>$ Salários a Pagar \\
\hline$\bullet$ Estoques & $>$ Encargos Sociais a Pagar \\
\hline$\bullet \quad$ Animais & \\
\hline Insumos & Exigível a Longo Prazo \\
\hline Permanente & $\triangleright$ Financiamentos Contraídos \\
\hline Imobilizado & \\
\hline$\bullet$ Veículos & Patrimônio Líquido \\
\hline$\bullet$ Benfeitorias & $>$ Capital Social \\
\hline$\bullet$ Terra & $>$ Lucros ou Prejuízos Acumulados \\
\hline$\bullet$ ( - ) Depreciação Acumulada & \\
\hline
\end{tabular}

Quadro 2 - Modelo da estrutura do balanço patrimonial utilizado para propriedades rurais.

Fonte: Adaptado pelo autor.

Não foi possível estimar a Conta Caixa e a conta Banco Conta Movimento, que é uma conta do Disponível do Ativo Circulante, por isso não serão calculados indicadores como o de Liquidez Corrente.

A conta de Crédito de Curto Prazo a Receber, que também faz parte do Ativo Circulante, foi formada por:

a) Conta a Receber de Clientes: considerou-se o valor referente a receita proveniente da venda de leite dos meses de outubro de 1997, setembro de 1998 e setembro de 1999, anotados na Folha de Diário (Anexo 2). Não se verificou a venda a prazo de animais.

b) Estoque de Animais: o valor inicial considerado é proveniente da Tabela 1.4 do Anexo 1. Embora animais reprodutores e de trabalho pertencem a imobilizado 
em andamento, optou-se por considerar os mesmo nesta conta de estoque. Para os outros balanços, o valor pode variar se o proprietário adquirir ou vender algum animal; então o valor considerado para os demais balanços foi calculado a partir da quantidade do rebanho escriturado no Anexo 3 e do preço por categoria de animal na época.

c) Estoque de Insumos: o valor inicial a ser considerado é proveniente da Tabela 1.5 do Anexo 1. Por razões metodológicas, o Projeto Leite não acompanhou o controle de estoque, por isso optou-se por considerar o mesmo valor para todos os balanços.

A conta de Imobilizado que faz parte do Ativo Permanente, foi formada por:

a) Veículos: o valor inicial considerado é proveniente do item veículo da Tabela 1.3 do Anexo 1. Para os outros balanços, o valor considerado pode variar se o proprietário adquirir ou vender algum veículo. Esta informação foi verificada através do Anexo 2 e a partir daí foram feitas as alterações para os demais balanços.

b) Máquinas e Equipamentos: o valor inicial a ser considerado é proveniente da Tabela 1.3 do Anexo 1, retirado o valor dos veículos. Para os outros balanços, o valor considerado pode variar se o proprietário adquirir ou vender alguma máquina ou equipamento. Através do Anexo 2 foram verificadas as alterações que foram consideradas para os demais balanços.

c) Benfeitorias: o valor inicial considerado é proveniente da Tabela 1.2 do Anexo 1, descontado o valor da depreciação correspondente a idade da benfeitoria, buscando com isso estimar o valor de mercado para as benfeitorias. Para os outros balanços, o valor considerado pode variar se o proprietário construir novas instalações. Através das anotações mensais no Anexo 2, as alterações verificadas foram consideradas para os demais balanços.

d) Terra: o valor inicial considerado é proveniente da Tabela 1.1 do Anexo 1 considerando o preço da terra conforme sua utilização. Para essa conta, nos demais balanços, utilizou-se o valor inicial, pois não se verificaram alterações 
no tamanho da área da propriedade e não se trabalhou com alterações no preço da terra.

e) Depreciação: o valor inicial considerado foi calculado através do método linear ${ }^{7}$, partindo das Tabelas 1.2 e 1.3 do Anexo 1 e sobre os animais de trabalhos relacionados na Tabela 1.4 do mesmo anexo. Não foi calculada a depreciação sobre animais de produção. Para os outros balanços, o valor da depreciação foi a soma do valor da depreciação do período anterior mais o valor da depreciação do período em análise, já consideradas as alterações no inventário relacionadas mensalmente nos Anexos 2 e 3.

As contas abordadas no Passivo Circulante são:

a) Dívidas com Fornecedores: o valor considerado nesta conta foi obtido através do Anexo 2, no qual o produtor escreveu os gastos que teve ao comprar ração, medicamentos, insumos em geral, e que foram descontados mensalmente na folha de pagamento do leite nos meses de outubro de 1997, setembro de 1998 e setembro de 1999.

b) Salários a Pagar e Encargos Sociais a Pagar: considerou o valor referente ao custo com mão-de-obra permanente proveniente dos meses de outubro de 1997, setembro de 1998 e setembro de 1999, anotados na Folha de Diário (Anexo 2).

No Exigível a Longo Prazo a conta foi:

a) Financiamentos Contraídos: no primeiro balanço patrimonial definido em outubro de 1997 foi considerado valor das dívidas relacionadas na Tabela 1.6 do Anexo 1 que foram assumidas em função da produção de leite. Para os demais balanços patrimoniais, os proprietários colocaram a disposição os extratos das dívidas requeridos junto às instituições financiadoras.

${ }^{7} \mathrm{O}$ método utilizado no cálculo da depreciação é o Método Linear: $D=\frac{(V I-V F)}{V U}$ onde: $\mathrm{D}=$ Depreciação; VI = Valor Inicial; VF = Valor Final ou Valor de Sucata; VU = Vida Útil Os VI e VU foram obtidos a partir do Anexo 02 e para o VF foi considerado $10 \%$ do VI para veículos e máquinas, $5 \%$ do VI para implementos, equipamentos e construções e VF igual a zero para animais de trabalho. 
O Patrimônio Líquido representa a parte da empresa que pertence ao(s) seu(s) proprietário(s). As contas que compõem o Patrimônio Líquido são:

a) Capital Social: considerou-se para todos os balanços, o valor obtido através da diferença entre Ativo Total e da soma entre Passivo Circulante mais Exigivel à Longo Prazo, do primeiro balanço patrimonial ${ }^{8}$.

b) Lucros ou Prejuizos Acumulados ${ }^{9}$ : para o primeiro balanço, considerou o valor igual a zero e nos demais balanços, o valor desta conta foi definido através da diferença entre o saldo anterior de Lucros ou Prejuízos Acumulados e o consumo familiar. Para o consumo familiar adotou-se o valor monetário equivalente a dois salários mínimos por mês. A este valor, foi somado o valor do lucro líquido do período.

Para complementar os dados necessários para o cálculo dos indicadores, calculou-se o Resultado do Exercício de cada propriedade (Quadro 3). Assim, por não disporem de um acompanhamento contábil rigoroso conforme as regras da contabilidade tradicional, algumas adaptações foram feitas para melhor adequar o modelo à realidade encontrada nas propriedades rurais pesquisadas. Novamente, chama-se a atenção para o fato de que os indicadores doravante calculados, também não exibem os valores fieis muitas vezes calculados para empresas urbanas, mas valores aproximados ao verdadeiro. Isso porque assim como no balanço patrimonial, não se obteve o resultado do exercício completo, conforme os rigores contábeis exigidos, mas sim uma aproximação.

${ }^{8}$ Pelo fato de o Ativo estar subestimado, o Capital também ficou abaixo de seu valor verdadeiro.

${ }^{9}$ É importante salientar que como o Projeto Leite não adotou controle de estoque nem reavaliação de veículos, máquinas, equipamentos, implementos e terra, não será possível ter a conta de Ajustes de Períodos Anteriores para calcular o valor de Lucros os Prejuízos Acumulados. Por também não ter feito controle sobre a Retirada do Proprietário esta conta não será considerada no cálculo do valor de Lucros os Prejuizos Acumulados. 


\begin{tabular}{|l|}
\hline \multicolumn{1}{|c|}{ DEMONSTRAÇÃO DE RESULTADO DO EXERCÍCIO } \\
\hline RENDA OPERACIONAL BRUTA \\
\hline RENDA OPERACIONAL LÍQUIDA \\
\hline ( - ) Custo de produção da quantidade produzida \\
\hline LUCRO BRUTO \\
\hline ( - ) Despesas com vendas \\
\hline ( - ) Despesas administrativas \\
\hline ( - ) Despesas financeiras \\
\hline LUCRO OPERACIONAL \\
\hline LUCRO ANTES DOS IMPOSTOS, CONTRIBUIÇÕES E PARTICIPAÇÕES \\
\hline LUCRO LÍQUIDO DO EXERCÍCIO \\
\hline
\end{tabular}

Quadro 3 - Modelo da estrutura da demonstração de resultado de exercício utilizado para propriedades Rurais.

Fonte: Adaptado pelo autor.

Devido a dificuldade de dividir a atividade de produção da atividade de cria e recria, considerou-se como renda operacional bruta o valor resultante do sistema de produção da fazenda, ou seja, a soma dos valores provenientes da produção de leite in natura e subprodutos vendidos, consumidos ou utilizados para pagamento; da venda e consumo de animais e da prestação de serviços que utilizaram bens do sistema de produção.

Especificamente, no caso destas propriedades rurais que desenvolvem a atividade leiteira, não existiram vendas canceladas, abatimento sobre vendas e impostos sobre vendas; logo, a renda operacional líquida é igual à renda operacional bruta.

Para apurar o lucro bruto, diminuiu-se da renda operacional líquida o valor referente ao custo de produção da quantidade produzida, que segundo Silva (1995), é calculado somando-se os insumos com a mão-de-obra direta mais os custos indiretos de produção (energia, depreciações, seguros e juros). Especificamente no caso de juros ou compensação sobre o capital, Hoffmann et al. (1978, p.59), define como sendo "a compensação que os donos dos fatores de produção, utilizados por uma firma 
para produzir determinado bem, devem receber para que eles continuem fornecendo esses fatores à mesma". Esse item de custo incidiu sobre as benfeitorias, máquinas, equipamentos e toda a classe de animais. Não se utilizou compensação sobre o capital de giro.

Do lucro bruto, diminuí-se as seguintes despesas:

a) Despesas com Vendas: neste caso são as despesas não computadas no custo mas necessárias à atividade da empresa, compreendendo frete do leite, ou seja, o custo para se transportar o leite da propriedade ao laticínio que veio escrito no Anexo 2.

b) Despesas Administrativas: compreende os gastos incorridos com as atribuições da administração geral, neste caso como só existe a atividade leiteira nas propriedades estudadas não se fez necessário utilizar-se do rateio. Basicamente, tal despesa foi compostas por gastos provenientes de serviços de contador quando este existiu.

c) Despesas Financeiras: neste caso, considerou os pagamentos referentes às taxas de renovação de conta e CPMF cobrados pelo banco. Não se coletou dados referentes ao pagamento de juros feitos à terceiros, provenientes de empréstimos, portanto, para o cálculo do retorno do capital total, não foi necessário acrescentar as despesas financeiras ao lucro líquido.

Após diminuir do lucro bruto tais despesas descritas acima, obtém-se o lucro operacional.

No caso específico destas propriedades, como não ocorreram alterações no inventário através de vendas ou compras de equipamentos e máquinas, portanto não possuíram receitas nem despesas não operacionais, logo o lucro operacional é igual ao lucro antes dos impostos, contribuições e participações. Como também não se adotou provisão para imposto de renda, para as participações e para contribuição social, visto que esta última contribuição já é um custo da mão-de-obra que vem descontado na folha de pagamento do leite, o lucro antes do imposto, contribuições e participações é o mesmo que lucro líquido do exercício. Logo, o lucro líquido do exercício é igual ao lucro operacional. 
Após montar o balanço patrimonial e o resultado do exercício para cada propriedade, seguiu-se com as avaliações financeira e econômica. Para avaliar a saúde financeira da empresa, utilizou-se o indicador de Endividamento. Para analisar a rentabilidade, utilizou-se o indicador de Retorno do Capital Total, decomposto em Margem Líquida sobre Vendas e Giro do Ativo. Esses indicadores foram calculados anualmente, permitindo assim, uma análise horizontal da sua evolução. Ė importante salientar que como os balanços e as demonstrações dos resultados do exercício não estão completos e até sub estimados, os valores que serão encontrados dos indicadores, Endividamento, Margem Líquida sobre Vendas, Giro do Ativo e Retorno do Capital Total, poderão estar sub ou superestimados.

A partir de dados fornecidos pelo Setor de Economia e Administração Rural da Escola de Agronomia da Universidade Federal de Goiás, fez-se a composição do custo total de produção, dividido em custo variável, fixo e em despesas, para posterior análise vertical do custo econômico da atividade leiteira.

Neste custo econômico não foi imputado a compensação pela utilização da terra, do capital de giro, da mão-de-obra familiar e do proprietário. Mas calculou-se a compensação pelo uso do capital investido ou juros sobre veículos, máquinas, equipamentos, benfeitorias, animais de produção e de trabalho; a depreciação e o seguro sobre veículos, máquinas, equipamentos, benfeitorias e animais de trabalho ${ }^{10}$.

A remuneração do capital investido foi feita multiplicando-se o valor médio do capital investido pela taxa anual de juros, neste caso foi de $6 \%$ a.a. Para determinar o valor médio, procedeu-se a soma entre o valor inicial e o valor final e dividiu-se tal soma por dois.

Remuneração sobre o capital $=\frac{(V I+V F)}{2} \times$ Taxa Unitária de Juros onde: $\mathrm{VI}=$ Valor Inicial;

\footnotetext{
${ }^{10}$ É importante salientar que estes critérios utilizados no cálculo da depreciação, seguro e juros foram referendados por vários pesquisadores sobre o assunto, no I Seminário sobre Metodologias de Cálculo do Custo de Produção de Leite, organizado pelo Centro de Estudos Avançados em Economia Aplicada CEPEA e Departamento de Produção Animal, ambos vinculados a Escola Superior de Agricultura "Luiz de Queiroz"- ESALQ/USP.
} 


$$
\mathrm{VF}=\text { Valor Final ou Valor de Sucata; }
$$

Para touro, o valor final considerado foi o valor referente à venda do mesmo com 20 arrobas ao preço de $\mathbf{R} \$ 22,00$ /arroba. Já para vaca, considerou-se o valor referente à venda da mesma com 13 arrobas ao preço de R\$ 18,00/arroba. Para veículos e máquinas o valor final considerado foi $10 \%$ do valor inicial, $5 \%$ para implementos, equipamentos e construções e zero para animais de trabalho.

No cálculo da depreciação utilizou-se o Método Linear, onde os valores iniciais e vida útil foram obtidos das Tabelas 1.2 e 1.3 do Anexo 1 e para o valor final considerou $10 \%$ do valor inicial para veículos e máquinas, $5 \%$ para implementos, equipamentos e construções e zero para animais de trabalho.

$$
\begin{aligned}
& D a=\frac{(V I-V F)}{V U} \quad \text { onde: } \mathrm{Da}=\text { Depreciação Anual; } \\
& \mathrm{VI}=\text { Valor Inicial; } \\
& \mathrm{VF}=\text { Valor Final ou Valor de Sucata; } \\
& \text { VU = Vida Útil, em anos; }
\end{aligned}
$$

$O$ valor imputado de seguro foi feito multiplicando-se o valor do capital médio investido pela taxa anual de seguros. A taxa de seguro considerada foi de $0,65 \%$ a.a.

$$
\begin{aligned}
& \text { Seguro }=\frac{(V I+V F)}{2} \times \text { Taxa Unitária de Seguro } \\
& \text { onde: } \mathrm{VI}=\text { Valor Inicial; } \\
& \mathrm{VF}=\text { Valor Final ou Valor de Sucata; }
\end{aligned}
$$

Os dados de custos variáveis, custos fixos de mão-de-obra e despesas, foram obtidos a partir das anotações diárias feitas pelos proprietários utilizando-se o Anexo 2. Essas anotações foram coletadas mensalmente, entre o período de outubro de 1997 a setembro de 1999 e através de um Programa de Banco de Dados organizado em Access, armazenou-se os dados obedecendo um plano de centro de custos (Anexo 4) e um plano de contas (Anexo 5) previamente definidos, utilizando-se os mesmos critérios para todos os produtores. 
Optou-se por analisar a participação relativa de itens do custo de produção, divididos em variáveis, fixos e despesas e estes subdivididos em alguns itens julgados importantes, como exemplo tem-se alimentos concentrados, mão-de-obra permanente, depreciações, seguro, despesas com vendas e outros. A composição percentual de cada item foi calculada mês a mês para cada propriedade de acordo com o custo de produção do mês em questão, e depois se calculou a média da participação percentual do item analisado durante o primeiro ano, segundo ano e durante o período todo. Para definir a composição percentual segundo o nível de produção, fez-se a média de cada item analisado a partir da média do somatório da participação relativa deste item em cada propriedade que faz parte do estrato.

Como exemplo:

Participação Alim entos Concentrados no Mês $s_{i}=\frac{\text { Gastos deste item no mês }}{\text { Custo de } \operatorname{Produção~do~mês~}} x 100$

Onde: $\mathrm{i}=$ janeiro, fevereiro, março, abril, maio, junho, julho, agosto, setembro, outubro, novembro e dezembro

Participação de Alimentos Concentrados do $\mathrm{Ano}_{\mathrm{j}}=$ Média do Somatório da Participação de Alimentos Concentrados no Mês $s_{i}$

Onde: $\mathrm{j}=1^{\circ}$ ano, $2^{\circ}$ ano e 24 Meses

Participação de Alimentos Concentrados por Estrato = Média do Somatório da Participação de Alimentos Concentrados do $\mathrm{Ano}_{\mathrm{j}}$ das Propriedades que compõem este Estrato $k$

Onde: $\mathrm{k}=$ Pequenos, Médios, Grandes e Amostra

Para calcular o custo econômico médio do leite, utilizou-se a quarta alternativa de fórmula proposta por Noronha et al. (1990), descrita no referencial teórico. Isso porque, tal alternativa segundo o mesmo autor, é a que apresenta menor influência 
quando se modificam os preços e as quantidades das variáveis que influenciam no resultado do cálculo.

Vale lembrar também, que não se considerou o rebanho estabilizado, o que significa que a renda total da atividade foi composta pela variação do rebanho entre $o$ início e fim do período considerado, utilizando-se para isso o preço de mercado dos animais e a variação na quantidade obtida através do Anexo 3. 


\section{RESULTADOS E DISCUSSÃO}

Num primeiro momento, realizou-se uma entrevista com os produtores rurais com objetivo de fazer uma breve caracterização das propriedades que compõem este estudo, comparando-a a outros trabalhos ${ }^{11}$.

Segundo a Faemg (1996), a distância média entre as propriedades de leite em Minas Gerais e o município mais próximo é de 13,94 km. Bressan et al. (1999) encontraram uma distância média de 14,6 km entre as propriedades de leite em Goiás e o município mais próximo, o que resulta em $3 \mathrm{~km}$ a menos que o encontrado nesta amostra. Embora as propriedades se localizem, em média, a 17,6 km distantes do município mais próximo, apresentam-se concentradas a uma distância de até $15 \mathrm{~km}$.

Os proprietários apresentam, em média, 14,3 anos dedicados à atividade leiteira, 3 anos a menos de experiência que o encontrado por Bressan et al. (1999) e 4,35 anos a menos que o encontrado pela Faemg (1996). A administração é realizada pelo proprietário em $80 \%$ das propriedades, ou pelo proprietário juntamente com sua família nos restantes $20 \%$. Os proprietários que residem na propriedade perfazem $55 \%$ da amostra, os demais vivem na cidade. A pesquisa de Bressan et al. (1999) apresenta um percentual maior de proprietários residente na fazenda (quase $66 \%$ contra $34 \%$ de proprietários residentes em cidades); já na pesquisa realizada pela Faemg (1996), do total de produtores de leite pesquisados em Minas Gerais, quase 37\% residem na fazenda, mas mesmo não residindo na fazenda não significa que seus proprietários não a

11 A comparação se deu com o trabalho publicado por Bressan et al. (1999), realizado em 710 propriedades do Estado de Goiás no ano de 1998 e com o trabalho da Faemg (1996), realizado em 996 propriedades do Estado de Minas Gerais no ano de 1995. 
administram ou vice-versa, pois segundo a mesma pesquisa, $64,17 \%$ das propriedades tem como principal administrador seu proprietário (Tabela 12).

Ainda segundo a Tabela $12,85 \%$ das propriedades contratam mão-deobra e apenas $15 \%$ das propriedades utilizam-se da mão-de-obra familiar para realizar as atividades contra $38,1 \%$ e $60,9 \%$ respectivamente, resultados apresentados por Bressan et al. (1999).

A amostra apresentou-se mais especializada na produção leiteira, pois enquanto a produtividade foi de $\mathbf{8 , 9 4}$ litros/vaca em lactação/dia, Bressan et al. (1999) verificaram uma produtividade de 5,1 e a Faemg (1996) encontrou uma produtividade de 4,9 litros/vaca em lactação/dia em sua pesquisa realizada no Estado de Minas Gerais.

Tabela 12. Características gerais das propriedades leiteiras do Estado de Goiás, comparadas a outras pesquisas.

\begin{tabular}{lllcc}
\hline \multirow{2}{*}{ VARIÁVEIS } & & UFG & FAEMG & BRESSAN \\
\cline { 3 - 4 } & Até $15 \mathrm{Km}$ & \multicolumn{3}{c}{ Em percentagem } \\
\hline \multirow{2}{*}{ Distância da fazenda ao } & De 15,1 a $25 \mathrm{Km}$ & 15,00 & \\
município & De 25,1 a $40 \mathrm{Km}$ & 10,00 & \\
& Acima de $40 \mathrm{Km}$ & 10,00 & & \\
Local de moradia do & Na cidade & 45,00 & & 34,10 \\
proprietário & Na fazenda & 55,00 & 36,89 & 65,90 \\
Administração & Só o Proprietário & 80,00 & 64,17 & 56,80 \\
& Proprietário e Família & 20,00 & & 36,90 \\
Mão-de-obra & Familiar & 15,00 & 61,90 \\
& Contratada & 85,00 & 38,10 \\
\hline
\end{tabular}

Fonte: Organizado pelo autor a partir dos dados do Projeto Leite.

Outros indicadores, como o uso de equipamentos e práticas inerentes a atividade, também demonstraram essa maior especialização da amostra. Enquanto $35 \%$ da amostra possui tanque de expansão, $40 \%$ resfriador de leite, $45 \%$ utilizam ordenha mecânica e $85 \%$ fazem inseminação artificial. Bressan et al. (1999), verificou em sua pesquisa que apenas $0,80 \%$ possuía tanque de expansão, $10,40 \%$ resfriador de leite, 
$2,90 \%$ utilizam ordenha mecânica e $13 \%$ faziam inseminação artificial. Já a pesquisa realizada no Estado de Minas Gerais pela Faemg (1996), verificou que 20,29\% possuem resfriador de leite, $4,65 \%$ utilizam ordenha mecânica e $11,24 \%$ fazem inseminação artificial (Tabela 13). Pode-se verificar que em ambas as pesquisas esses indicadores estão muito abaixo dos encontrados nesta amostra. Verificou-se também, que $90 \%$ dos produtores da amostra utilizam suplementação alimentar para os animais na época da seca, especificamente para os animais em lactação, na relação de 1 quilograma de concentrado para cada 3 litros de leite produzido.

Tabela 13. Indicadores de especialização da produção leiteira, em percentagem, estratificados por nível de produção, comparados a outras pesquisas.

\begin{tabular}{|c|c|c|c|c|c|c|}
\hline \multirow{2}{*}{ VARIÁVEIS } & \multicolumn{4}{|c|}{ AMOSTRA } & \multirow{2}{*}{ BRESSAN } & \multirow{2}{*}{ FAEMG } \\
\hline & Pequeno & Médio & Grande & Geral & & \\
\hline Resfriador de Leite & 37,50 & 50,00 & 33,33 & 40,00 & 10,40 & 20,29 \\
\hline Tanque de Expansão & 12,50 & 33,33 & 66,67 & 35,00 & 0,80 & \\
\hline \multicolumn{7}{|l|}{ Ordenha: } \\
\hline - Mecânica & 25,00 & 16,67 & 100,00 & 45,00 & 2,90 & 4,65 \\
\hline - Manual & 75,00 & 83,33 & 0,00 & 55,00 & 97,00 & 94,21 \\
\hline Inseminação Artificial & 75,00 & 83,33 & 100,00 & 85,00 & 13,00 & 11,24 \\
\hline Monta natural $^{1}$ & 25,00 & 16,67 & 0,00 & 15,00 & 87,00 & 88,76 \\
\hline
\end{tabular}

Fonte: Organizado pelo autor.

${ }^{1}$ Resultado encontrado por diferença ( $100 \%$ - \% de Inseminação Artificial).

Estratificando esta amostra por tamanho da atividade ${ }^{12}$, considerando para isso o volume de produção, em que pequenos produtores são aqueles com produção diária de até 200 litros de leite; médios produtores, de 201 a 500 litros de leite por dia e grandes produtores aqueles com produção diária de leite acima de 500 litros, verificou-

\footnotetext{
${ }^{12}$ É importante ressaltar que esta estratificação não utilizou nenhum critério estatístico e que a amostra não é representativa para o Estado de Goiás, já que é composta por apenas 20 propriedades.
} 
se que à medida que se aumentou o nível de produção, a intensificação no uso do capital aumentou (Tabela 13).

Analisando a composição do custo, verificou-se que não houve alterações acentuadas do primeiro ano (outubro de 1997 a setembro de 1998) para o segundo ano (outubro de 1998 a setembro de 1999). Ao analisar a média dos 24 meses, encontrou-se que $52,68 \%$ do custo total é proveniente dos custos variáveis, $37,78 \%$ dos custos fixos e 9,55\% das despesas (Figura 2).

É importante enfatizar a necessidade de especificar, em termos relativos, quais os itens que compõem a estrutura do custo de produção, podendo-se assim, identificar quais são os que mais participam no custo. Desta forma, ao analisar a Tabela 14, verificou-se que o principal item que contribuiu para a composição dos custos variáveis foi alimentos concentrados, já para custos fixos foi mão-de-obra permanente e em despesa foram as despesas com vendas.

Toledo (2000), após estudar uma propriedade no município de IpameriGO, alertou para a importância do item alimentação na composição do custo total, verificou um valor próximo a $50 \%$ considerando os gastos com volumoso e concentrado.

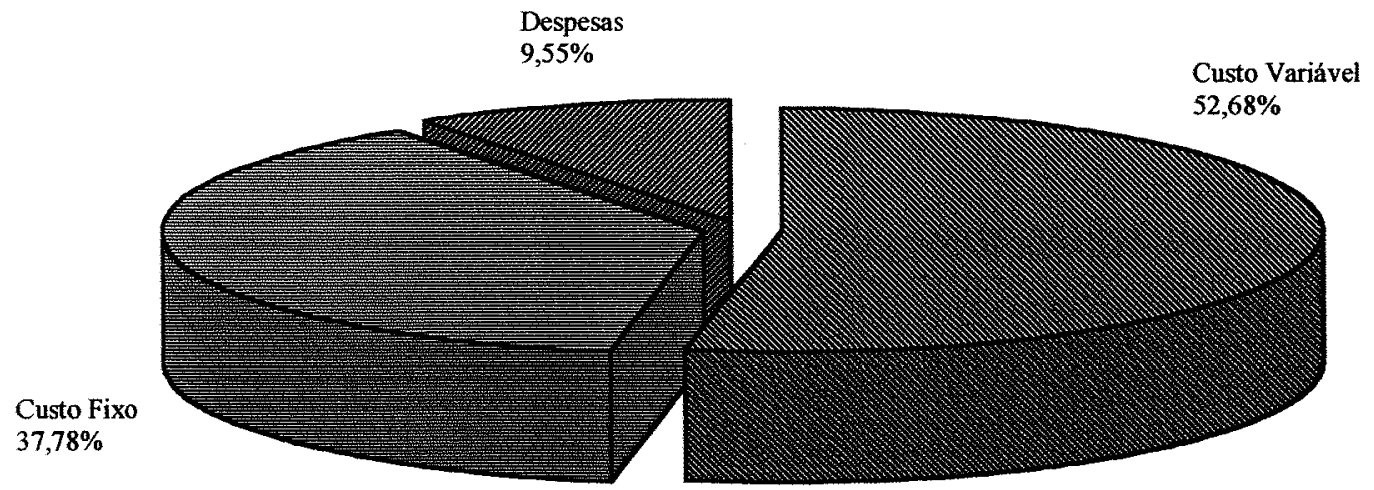

Figura 2 - Composição do custo total de produção de propriedades leiteiras no Estado de Goiás, de 1997/99.

Fonte: Organizado pelo autor a partir dos dados do Projeto Leite. 
Tabela 14. Composição percentual do custo total de produção de propriedades leiteiras no Estado de Goiás, no período de outubro de 1997 a setembro de 1999.

\begin{tabular}{|c|c|c|c|}
\hline \multirow{2}{*}{ ITENS } & \multicolumn{3}{|c|}{ AMOSTRA } \\
\hline & $1^{\circ} \mathrm{ANO}$ & $2^{\circ} \mathrm{ANO}$ & 24 MESES \\
\hline CUSTO VARIÁVEL & 53,12 & 51,00 & 52,68 \\
\hline Mão-de-obra Temporária & 2,33 & 1,62 & 1,97 \\
\hline Serviços de Terceiros & 3,56 & 2,11 & 2,85 \\
\hline Serviços Mecanizados & 5,90 & 4,45 & 5,31 \\
\hline Corretivos e Fertilizantes & 5,93 & 5,24 & 5,78 \\
\hline Sementes e Mudas & 0,72 & 0,89 & 0,82 \\
\hline Defensivos e Herbicidas & 0,32 & 0,87 & 0,58 \\
\hline Alimentos Concentrados & 19,77 & 19,97 & 20,06 \\
\hline Alimentos Volumosos & 0,24 & 1,94 & 1,06 \\
\hline Inseminação Artificial & 1,67 & 1,44 & 1,58 \\
\hline Vacinas e Medicamentos & 6,23 & 5,36 & 5,88 \\
\hline Material de Consumo & 1,20 & 1,22 & 1,17 \\
\hline Outros Custos Variáveis & 5,26 & 5,89 & 5,63 \\
\hline CUSTO FIXO & 37,54 & 38,94 & 37,78 \\
\hline Mão-de-obra Permanente & 15,05 & 15,67 & 15,26 \\
\hline Manutenção e Reparos & 1,38 & 0,46 & 0,93 \\
\hline Aluguéis e Arrendamentos & 0,59 & 0,56 & 0,59 \\
\hline Taxas, Impostos e Licenças & 0,62 & 0,38 & 0,47 \\
\hline Depreciações & 13,07 & 14,41 & 13,50 \\
\hline Seguros e Juros & 6,82 & 7,47 & 7,03 \\
\hline DESPESAS OPERACIONAIS & 9,34 & 10,08 & 9,55 \\
\hline Despesas com Vendas & 4,82 & 5,40 & 5,03 \\
\hline Despesas Administrativas & 3,41 & 3,48 & 3,40 \\
\hline Despesas Financeiras & 0,27 & 0,14 & 0,18 \\
\hline Outras Despesas & 0,84 & 1,06 & 0,94 \\
\hline TOTAL (Custos+Despesas) & 100,00 & 100,00 & 100,00 \\
\hline
\end{tabular}

Fonte: Organizado pelo autor a partir dos dados do Projeto Leite.

Quando se analisa a composição do custo total de produção considerando o nível de produção, dividindo a amostra em produtores pequenos, médios e grandes, verifica-se a medida que aumenta a produção a participação relativa dos custos variáveis aumenta e a dos custos fixos diminui (Tabela 15 e Figura 3). Especificamente, a participação do item alimentos concentrados aumenta, e a participação dos itens 
depreciação e outras despesas (consumo de leite pelo proprietário) diminuem (Tabela 15).

Ainda seguindo esta análise de participação dos itens na composição do custo total (Tabela 15), verifica-se a mão-de-obra permanente teve uma contribuição em torno de $15 \%$ no custo total, independente do nível de produção.

Tabela 15. Composição percentual do custo total de produção de propriedades leiteiras no Estado de Goiás, segundo o nível de produção, no período de outubro de 1997 a setembro de 1999.

\begin{tabular}{lrrr}
\hline \multirow{2}{*}{ ITENS } & \multicolumn{3}{c}{ CATEGORIA } \\
\cline { 2 - 4 } \multicolumn{1}{c}{ CUSTO VARIÁVEL } & PEQUENOS & MÉDIOS & GRANDES \\
\hline Mão-de-obra Temporária & 49,92 & 51,39 & 57,66 \\
Serviços de Terceiros & 3,05 & 1,38 & 2,45 \\
Serviços Mecanizados & 3,38 & 2,93 & 2,06 \\
Corretivos e Fertilizantes & 4,63 & 4,84 & 6,70 \\
Sementes e Mudas & 5,32 & 3,77 & 8,42 \\
Defensivos e Herbicidas & 1,25 & 0,65 & 0,42 \\
Alimentos Concentrados & 0,40 & 0,33 & 1,06 \\
Alimentos Volumosos & 17,44 & 20,90 & 22,71 \\
Inseminação Artificial & 0,95 & 1,25 & 1,00 \\
Vacinas e Medicamentos & 1,49 & 1,18 & 2,11 \\
Material de Consumo & 5,70 & 6,42 & 5,57 \\
Outros Custos Variáveis & 1,26 & 0,74 & 1,47 \\
$\quad$ CUSTO FIXO & 6,06 & 7,00 & 3,68 \\
Mão-de-obra Permanente & 40,44 & 37,88 & 34,14 \\
Manutenção e Reparos & 14,96 & 15,77 & 15,14 \\
Aluguéis e Arrendamentos & 1,12 & 0,60 & 1,02 \\
Taxas, Impostos e Licenças & 1,20 & 0,39 & 0,00 \\
Depreciações & 0,30 & 0,74 & 0,43 \\
Seguros e Juros & 15,99 & 12,24 & 11,44 \\
DESPESAS OPERACIONAIS & 6,88 & 8,14 & 6,12 \\
Despesas com Vendas & 9,61 & 10,82 & 8,20 \\
Despesas Administrativas & 4,97 & 5,99 & 4,15 \\
Despesas Financeiras & 3,25 & 3,81 & 3,18 \\
Outras Despesas & 0,15 & 0,05 & 0,37 \\
TOTAL(Custos+Despesas) & 1,23 & 0,97 & 0,50 \\
\hline
\end{tabular}

Fonte: Organizado pelo autor a partir dos dados do Projeto Leite. 


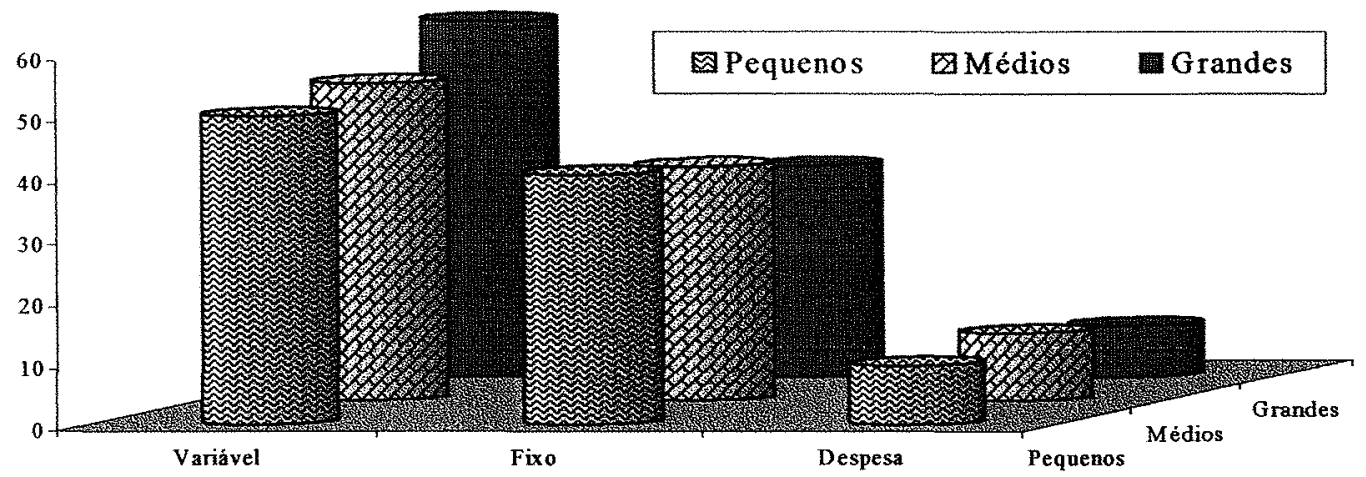

Figura 3 - Composição percentual do custo total de produção de propriedades leiteiras no Estado de Goiás, segundo o nível de produção, de 1997/99.

Fonte: Organizado pelo autor a partir dos dados do Projeto Leite.

Dividindo-se o período do estudo em anos, verifica-se que o custo total médio ou custo unitário do leite diminuiu do primeiro para o segundo ano e o preço médio recebido aumentou, em valores nominais. Mas, ao dividir a amostra em tamanho, utilizando a produção diária como critério, observa-se que os pequenos produtores aumentaram o custo total médio. Já os médios e os grandes produtores conseguiram diminuir, apresentando uma redução de 24,14 e 12,50\%, respectivamente. Em todos os estratos, o preço médio recebido aumentou (Tabela 16).

Ainda segundo a Tabela 16, ao se considerar o periodo todo, 24 meses, analisando a diferença entre preço médio recebido e custo total médio, nota-se uma pequena vantagem dos médios produtores em relação aos pequenos e aos grandes produtores, embora os três estratos tenham apresentado custo total médio maior que o preço recebido.

Faemg (1996), verificou que à medida que se aumenta a produção diária de leite, consegue-se reduzir o custo médio, embora a tabela abaixo não demonstra tal relação. 
Tabela 16. Custo médio de produção e preços recebidos, em $\mathrm{R} \$$ por litros, Estado de Goiás, 1997/99.

\begin{tabular}{lccc}
\hline \multicolumn{1}{c}{ CATEGORIA } & \multicolumn{3}{c}{ Período } \\
\cline { 2 - 4 } \multicolumn{1}{c}{ PEQUENOS } & $1^{\circ}$ ANO & $2^{\circ}$ ANO & 24 MESES \\
\hline \multicolumn{1}{c}{$\begin{array}{l}\text { Pusto total médio } \\
\quad \text { MÉDIOS }\end{array}$} & 0,27 & 0,34 & 0,28 \\
Preço médio recebido & 0,22 & 0,24 & 0,23 \\
$\quad$ Custo total médio & 0,29 & 0,22 & 0,24 \\
Preço médio recebido & 0,22 & 0,23 & 0,23 \\
$\quad$ GRANDES & 0,32 & 0,28 & 0,29 \\
Custo total médio & 0,24 & 0,26 & 0,25 \\
Preço médio recebido & & & \\
$\quad$ AMOSTRA & 0,29 & 0,28 & 0,27 \\
Custo total médio & 0,22 & 0,24 & 0,23 \\
Preço médio recebido & & & \\
\hline
\end{tabular}

Fonte: Organizado pelo autor a partir dos dados do Projeto Leite.

Avaliando a lucratividade total da atividade através do lucro líquido que se obteve pela diferença entre receita operacional bruta e da soma custo do produto vendido mais despesas (Tabela 17), a amostra toda ou estratificada segundo o tamanho, apresentou resultado positivo no segundo ano e negativo no primeiro, exceção se faz no caso dos pequenos produtores que apresentaram resultado negativo nos dois anos.

Em todos os estratos houve melhora no que se refere ao resultado do lucro líquido de um ano para o outro. No caso dos pequenos produtores, embora apresentaram uma melhora no lucro líquido, não foi suficiente para reverter a situação negativa no primeiro ano. Já os grandes produtores, conseguiram reverter esta situação do $1^{\circ}$ para 0 $2^{\circ}$ ano, mas a média dos dois anos continuou negativa. Só os médios produtores conseguiram melhorar o lucro líquido que além de apresentar positivo no segundo ano, apresentou positivo no período todo. 
Tabela 17. Lucratividade total da atividade leiteira, em R\$ por mês, segundo o tamanho do produtor, no Estado de Goiás, $1997 / 99$.

\begin{tabular}{lrrr}
\hline \multirow{2}{*}{ CATEGORIA } & \multicolumn{3}{c}{ Período } \\
\cline { 2 - 4 } \multicolumn{1}{c}{ PEQUENOS } & \multicolumn{1}{c}{$\mathbf{1}^{\circ}$ ANO } & $2^{\circ}$ ANO & 24 MESES \\
\hline Receita Operacional Bruta & 1379,93 & 1395,94 & 1393,61 \\
Custo dos Produtos Vendidos + Despesas & 1563,48 & 1463,49 & 1516,67 \\
Lucro Líquido & $-183,56$ & $-67,55$ & $-123,06$ \\
\multicolumn{1}{c}{ MÉDIOS } & & & \\
Receita Operacional Bruta & 2188,55 & 3236,12 & 2707,22 \\
Custo dos Produtos Vendidos + Despesas & 2472,42 & 2524,90 & 2496,24 \\
Lucro Líquido & $-283,88$ & 711,21 & 210,97 \\
\multicolumn{1}{c}{ GRANDES } & & & \\
Receita Operacional Bruta & 7207,68 & 8276,99 & 7717,81 \\
Custo dos Produtos Vendidos + Despesas & 8355,17 & 7859,46 & 8107,81 \\
Lucro Líquido & $-1147,48$ & 417,54 & $-390,01$ \\
\multicolumn{1}{c}{ AMOSTRA } & & & \\
Receita Operacional Bruta & 3370,84 & 4012,31 & 3684,95 \\
Custo dos Produtos Vendidos + Despesas & 3873,67 & 3700,70 & 3787,88 \\
Lucro Líquido & $-502,83$ & 311,60 & $-102,93$ \\
\hline
\end{tabular}

Fonte: Organizado pelo autor a partir dos dados do Projeto Leite.

Partindo para análise do balanço patrimonial, verifica-se que $45 \%$ das propriedades estudadas ( 9 propriedades) tiveram taxa de crescimento do ativo negativa; $35 \%$ ( 7 propriedades) com taxa de crescimento entre 0,1 a $2 \%$ e $20 \%$ das propriedades (4 propriedades) tiveram taxa de crescimento acima de $2 \%$ (Figura 4), apresentando $16 \%$ ao ano como limite máximo de crescimento do ativo em uma propriedade. 


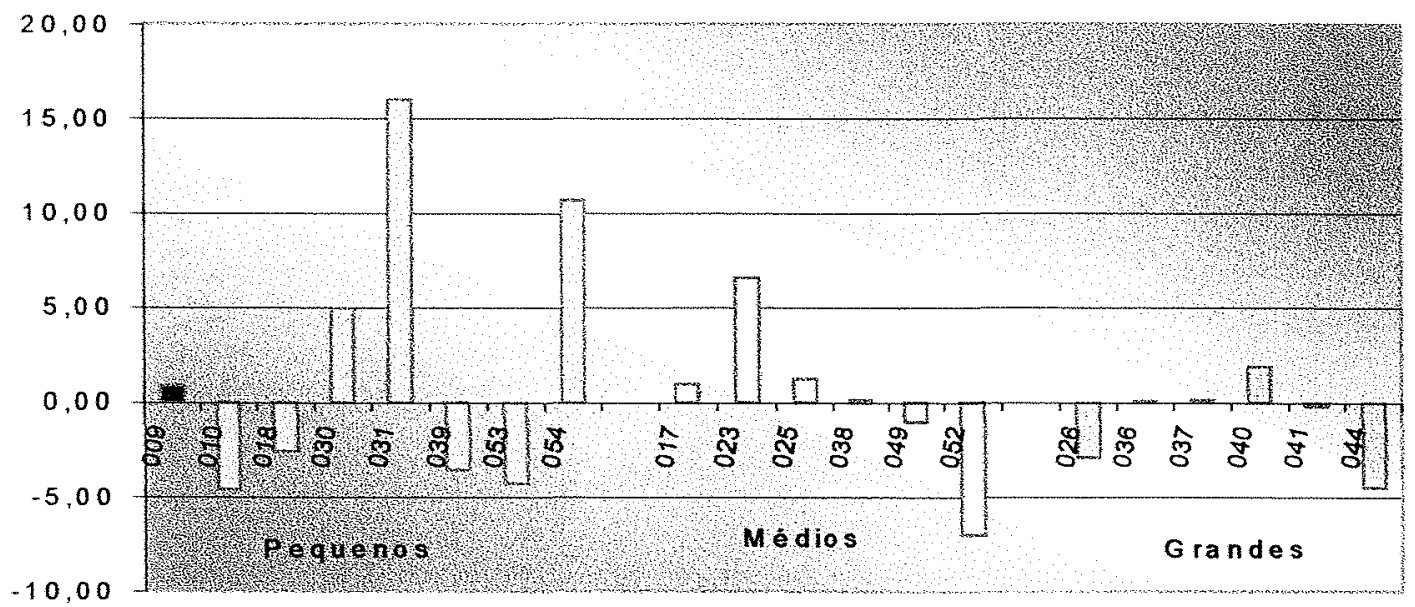

Figura 4 - Taxa de crescimento do ativo, em percentagem, de propriedades leiteiras no Estado de Goiás, de 1997/99.

Fonte: Organizado pelo autor a partir dos dados do Projeto Leite.

Analisando a amostra estratificada, do total das pequenas propriedades, $50 \%$ apresentaram percentual de crescimento negativo do ativo, $33,33 \%$ das médias e $50 \%$ das grandes propriedades analisadas também apresentaram percentual de crescimento negativo do ativo (Figura 4).

Verificando as propriedades com grau de endividamento acima de 5\%, observou-se que as pequenas propriedades estão em maior número absoluto quando comparadas às médias e grandes propriedades e foram as que mais conseguiram diminuir o grau de endividamento no período de 1997 a 1999. Já as grandes propriedades apresentaram maior grau de endividamento no mesmo período (Tabela 18). As dívidas de longo prazo das propriedades são provenientes, na maioria, devido à compra de animais e melhoria da estrutura, com aquisição de tanque de expansão e ordenhadeira mecânica, financiados através do FCO, Fundo Centro-Oeste, ou pelos laticínios. 
Tabela 18. Grau de endividamento de propriedades leiteira, em percentagem, segundo o tamanho do produtor, no Estado de Goiás, 1997/99.

\begin{tabular}{crrr}
\hline \multirow{2}{*}{ CATEGORIA } & \multicolumn{3}{c}{ Grau de Endividamento (\%) } \\
\cline { 2 - 4 } PEQUENOS & 1997 & 1998 \\
009 & 17,57 & 17,57 & 1999 \\
010 & 10,09 & 8,09 & 7,29 \\
018 & 0,30 & 0,32 & 0,39 \\
030 & 12,00 & 16,42 & 14,52 \\
031 & 23,10 & 22,20 & 17,84 \\
039 & 6,10 & 3,62 & 1,63 \\
053 & 0,37 & 1,24 & 0,66 \\
054 & 18,50 & 15,22 & 13,83 \\
MÉDIOS & & & \\
017 & 0,00 & 7,22 & 4,08 \\
023 & 6,34 & 0,76 & 0,27 \\
025 & 1,72 & 1,14 & 0,67 \\
038 & 0,20 & 0,05 & 0,06 \\
049 & 12,93 & 11,50 & 11,38 \\
052 & 5,01 & 3,38 & 0,13 \\
GRANDES & & & \\
026 & 0,08 & 0,13 & 0,08 \\
036 & 1,81 & 0,31 & 3,06 \\
037 & 27,27 & 28,82 & 22,97 \\
040 & 24,93 & 25,86 & 24,88 \\
041 & 0,24 & 0,92 & 0,74 \\
044 & 24,16 & 29,28 & 32,12 \\
\hline
\end{tabular}

Fonte: Organizado pelo autor a partir dos dados do Projeto Leite.

As propriedades 023, 039 e 052 conseguiram liquidar suas dívidas (Tabela 18) após as negociações feitas no início de 1999 com as instituições financeiras. Isso só foi possível, especificamente para a primeira propriedade, após aumentar sua produção de leite e para as duas últimas propriedades, após os proprietários venderem parte de seu rebanho o que resultou em taxa de crescimento negativa do ativo total (Figura 4). Mas, verificou-se que as propriedades 031 e 054, conseguiram reduzir seu grau de endividamento (Tabela 18) e obter taxa de crescimento do ativo positiva (Figura 4). Nesses casos, a principal variável responsável foi o aumento da receita total, 
proveniente do aumento da produção de leite, o que lhes permitiu saldar parte das dívidas contraídas.

Analisando as três grandes propriedades da pesquisa que apresentaram maior grau de endividamento (Tabela 18), uma apresentou crescimento próximo de zero, outra apresentou taxa positiva, mas as custas de capital de terceiros, e a última apresentou taxa de crescimento do ativo total negativa (Figura 4).

Observando o indicador de retorno do capital total (Tabela 19), verificouse que das 20 propriedades analisadas nesta pesquisa, 17 conseguiram, de 1997/98 para 1998/99, melhorar esse indicador, o que representa $85 \%$ da amostra.

Estratificando as propriedades por tamanho, nota-se que todas as pequenas propriedades conseguiram melhorar o retorno do capital total no ano 1998/99, mesmo aquelas que continuaram a ter percentual negativo.

Analisando as médias propriedades, quatro delas melhoraram o retorno do capital total, o que representa $66,67 \%$ destas propriedades. Isso se deve principalmente porque das que tinham valor negativo em 1997/98, três conseguiram valor positivo em 1998/99. Entre as grandes propriedades, quase $67 \%$ conseguiram passar de um valor negativo em 1997/98 para o positivo em 1998/99. Apenas uma propriedade continuou a apresentar um valor negativo, embora tenha melhorado um pouco. 
Tabela 19. Margem líquida sobre vendas, giro do ativo e retorno do capital total de propriedades leiteira, segundo o tamanho do produtor, no Estado de Goiás, $1997 / 99$.

\begin{tabular}{|c|c|c|c|c|c|c|}
\hline \multirow[b]{2}{*}{ CATEGORIA } & \multicolumn{3}{|c|}{$1997 / 1998$} & \multicolumn{3}{|c|}{$1998 / 1999$} \\
\hline & $\begin{array}{l}\text { Margem } \\
\text { Líquida }\end{array}$ & $\begin{array}{l}\text { Giro do } \\
\text { Ativo }\end{array}$ & $\begin{array}{c}\text { Retorno do } \\
\text { Capital Total } \\
(\%) \\
\end{array}$ & $\begin{array}{l}\text { Margem } \\
\text { Líquida }\end{array}$ & $\begin{array}{l}\text { Giro do } \\
\text { Ativo }\end{array}$ & $\begin{array}{l}\text { Retorno do } \\
\text { Capital Total } \\
(\%)\end{array}$ \\
\hline \multicolumn{7}{|l|}{ PEQUENOS } \\
\hline 009 & 0,26 & 0,13 & 3,38 & 0,25 & 0,17 & 4,25 \\
\hline 010 & 0,10 & 0,18 & 1,80 & 0,42 & 0,20 & 8,40 \\
\hline 018 & 0,09 & 0,19 & 1,71 & 0,14 & 0,19 & 2,66 \\
\hline 030 & 0,22 & 0,22 & 4,84 & 0,17 & 0,33 & 5,61 \\
\hline 031 & $-0,36$ & 0,13 & $-4,68$ & $-0,05$ & 0,26 & $-1,30$ \\
\hline 039 & 0,06 & 0,15 & 0,90 & 0,27 & 0,15 & 4,05 \\
\hline 053 & $-0,81$ & 0,14 & $-11,34$ & $-1,10$ & 0,08 & $-8,80$ \\
\hline 054 & $-0,61$ & 0,12 & $-7,32$ & $-0,71$ & 0,08 & $-5,68$ \\
\hline \multicolumn{7}{|l|}{ MÉDIOS } \\
\hline 017 & 0,43 & 0,38 & 16,34 & 0,48 & 0,37 & 17,76 \\
\hline 023 & 0,54 & 0,38 & 20,52 & 0,33 & 0,31 & 10,23 \\
\hline 025 & $-1,04$ & 0,05 & $-5,20$ & 0,08 & 0,11 & 0,88 \\
\hline 038 & $-0,39$ & 0,02 & $-0,78$ & $-0,54$ & 0,02 & $-1,08$ \\
\hline 049 & $-0,24$ & 0,12 & $-2,88$ & 0,02 & 0,15 & 0,30 \\
\hline 052 & $-0,33$ & 0,14 & $-4,62$ & 0,40 & 0,17 & 6,80 \\
\hline \multicolumn{7}{|l|}{ GRANDES } \\
\hline 026 & $-0,10$ & 0,06 & $-0,60$ & 0,30 & 0,11 & 3,30 \\
\hline 036 & $-0,28$ & 0,24 & $-6,72$ & 0,25 & 0,33 & 8,25 \\
\hline 037 & 0,25 & 0,63 & 15,75 & 0,02 & 0,37 & 0,74 \\
\hline 040 & $-0,47$ & 0,08 & $-3,76$ & $-0,09$ & 0,12 & $-1,08$ \\
\hline 041 & $-0,29$ & 0,08 & $-2,32$ & 0,11 & 0,12 & 1,32 \\
\hline 044 & $-0,17$ & 0,20 & $-3,40$ & 0,02 & 0,20 & 0,40 \\
\hline
\end{tabular}

Fonte: Organizado pelo autor a partir dos dados do Projeto Leite.

Para verificar quais as causas que levaram à melhoria do retorno do capital total, este foi dividido, pelo Método DuPont, em margem líquida sobre vendas e em giro do ativo.

Observa-se que 11 propriedades, 55\%, conseguiram melhorar o retorno do capital total, utilizando a alternativa de aumentar a margem líquida e o giro do ativo. 
Destas propriedades, apenas duas continuaram com retorno do capital total negativo, mas um valor menor que o apresentado no ano 1997/98. Duas propriedades melhoraram o retorno do capital total, através do aumento da margem líquida e diminuição do giro do ativo. A alternativa utilizada por duas outras propriedades foi aumentar o giro do ativo já que ocorreu redução da margem líquida. Uma quarta alternativa utilizada, também por duas propriedades, foi diminuição do giro e da margem líquida, mas neste caso o retorno do capital total continuou negativo, o que os produtores buscaram foi tentar minimizar o prejuízo (Tabela 19).

Analisando as variáveis que compõem a fórmula DuPont, verificou-se que o giro do ativo tem relação linear mais forte com o resultado do retorno do capital total do que margem líquida sobre vendas e retorno do capital total. Isto porque o coeficiente de correlação entre giro do ativo e retorno do capital total é maior que o coeficiente de correlação entre margem líquida sobre vendas e retorno do capital total, 0,4671 e 0,4048 respectivamente.

A variável produção de leite apresentou pouca relação linear com o retorno do capital total, pois o coeficiente de correlação foi de apenas 0,0427 , embora a correlação entre a produção de leite e o giro do ativo tenha apresentado resultado de 0,2681. Já a correlação entre retorno do capital total e lucro líquido apresentou uma relação linear forte, com coeficiente igual a 0,7701. Quando calculado o coeficiente de correlação entre as variáveis lucro líquido e receita proveniente da venda de leite, lucro líquido e produção, lucro líquido e preço do leite e, lucro líquido e receita proveniente da venda de animais, verificou-se os seguintes coeficientes: 0,$2562 ; 0,1977 ; 0,2405 \mathrm{e}$ 0,5709 , respectivamente. Isto pode ser um indício da dificuldade da sustentabilidade da atividade leiteira baseada exclusivamente na produção de leite. Noronha et al. (2001), já haviam verificado a importância da venda de animais na composição da receita e no desempenho econômico da pecuária de leite. 


\section{CONCLUSÕES}

Várias foram as dificuldades encontradas para a realização desta pesquisa. A primeira foi ao se definir o tamanho da amostra de forma a satisfazer os preceitos estatísticos e atender à restrição orçamentária imposta pelo agente financiador. Acompanhar mensalmente propriedades rurais em diferentes municípios requer muito tempo e recurso financeiro. Por isso, em discussão com as instituições que apoiaram a pesquisa, chegou-se à conclusão que a alternativa, técnica e financeiramente viável, era o estudo de casos que representassem as principais bacias leiteiras do Estado. Fortaleceu esta decisão o fato de que estava em andamento uma pesquisa desenvolvida por Bressan et al. (1999), cujo objetivo básico era fazer um amplo diagnóstico da pecuária de leite, baseada em uma amostra estratificada representativa para o Estado de Goiás. Faltava, no entanto, um aprofundamento nas questões de custos, produtividade e rentabilidade da atividade leiteira. $O$ levantamento mensal deveria preencher esta lacuna.

Outra dificuldade encontrada foi na escolha de critérios que definem a estratificação da amostra segundo o nível de produção em pequeno, médio ou grande produtor de leite. Isto porque não se conhecem critérios científicos que definam essa estratificação. Em geral os pesquisadores da área adotam critérios coerentes com os objetivos específicos de cada pesquisa. A estratificação usada neste estudo não foge ao costume vigente, apenas acrescentou a opinião dos próprios produtores e seus representantes de classe quando se elaborou o projeto da pesquisa.

Como qualquer outro estudo de casos, os resultados permitem algumas inferências no que diz respeito à situação econômica da atividade leiteira no Estado de Goiás. Isto porque a metodologia de acompanhamento mensal, permitiu uma melhor 
aproximação da real situação ocorrida na produção de leite das propriedades estudadas e a análise dos resultados econômicos e financeiros da atividade leiteira. Todavia é importante ressaltar a necessidade de se tomar as devidas precauções ao analisar os resultados e reconhecer as limitações do método bem como o alcance das conclusões dele derivadas.

Por exemplo, a caracterização das propriedades mostra que os casos estudados utilizam tecnologia de produção um pouco acima do que se observa na média dos Estados de Goiás e Minas Gerais. Mas, contrariando a opinião de alguns estudiosos, a utilização de tecnologia avançada (entendida como uso de ordenha mecânica, inseminação artificial, etc.) não levou à maior rentabilidade da atividade. Assim, observou-se a ocorrência de lucro líquido negativo em algumas propriedades que utilizaram essa tecnologia e de lucro líquido positivo em propriedades que não utilizaram essas tecnologias.

Embora pesquisas indiquem que à medida que se aumenta a produção diária de leite consegue-se reduzir o custo médio, não se verificou tal relação. $O$ fato é que, em regra geral, os produtores aumentam a produção fornecendo mais ração para os animais, logo, há de se tomar cuidado com essa alternativa, pois o item alimentação é o que mais participa na composição do custo total.

Outra importante conclusão diz respeito à fraca correlação entre o lucro líquido da atividade e as variáveis, produção e preço do leite (coeficiente de correlação abaixo de $\mathbf{0 , 2 5}$ ). De fato, lucro líquido e venda de animais apresentaram coeficiente de correlação linear simples de 0,57 , bem maior do que as variáveis anteriores.

Observou-se, também, que à medida que a produção aumentou o grau de endividamento diminuiu, em grande parte, também devido à venda do leite e de animais.

Analisando o resultado econômico da atividade através do indicador retorno do capital total, verificou-se que a maioria dos produtores melhora este indicador de um ano para o outro através do aumento tanto da margem líquida sobre vendas como do giro do ativo. Mas, quando o lucro líquido for negativo, o produtor sempre terá retorno do capital total negativo, mesmo que a receita operacional líquida aumente. 
Comparando-se o preço médio recebido pelo produtor rural com o custo médio, conclui-se que a conjuntura encontra-se desfavorável, dificultando a permanência do produtor nesta atividade. Vale lembrar que em qualquer nível de produção ou de tecnologia, existem produtores ganhando e outros perdendo dinheiro, o que evidência ainda mais, a importância de se avaliar economicamente os resultados da atividade, permitindo desta forma um melhor gerenciamento da propriedade através de uma melhor alocação dos recursos produtivos.

Conclui-se, também, que a utilização de um sistema de controle de custo gerencial, quando associado com a utilização de indicadores financeiros, permite uma avaliação mais completa dos resultados da atividade leiteira. Entretanto, muito ainda está para ser feito nesta área para assegurar melhor entendimento desta atividade no Brasil.

Neste sentido, sugere-se novas pesquisas que desenvolvam fórmulas que calculam o custo médio e sofram menos influência quando variar o preço dos produtos e pesquisas para definir quais os indicadores de fácil compreensão aos produtores.

É importante ressaltar atenção especial para os seguintes pontos em futuras pesquisas sobre análise financeira de propriedades rurais:

- Na medida do possível buscar trabalhar com balanço patrimonial e resultados do exercício completos;

- Uso de amostra com representatividade estatística, ainda que regionalizada;

- Prazo de coleta dos dados mais longo;

- Uniformização de critérios de cálculos para tornar resultados comparáveis; 
ANEXOS 
ANEXO 1 - Questionário Utilizado para Pesquisa de Inventário.

Projeto: “Análise da Rentabilidade da Atividade Leiteira no Estado de Goiás"

FAEG / SEBRAE-GO / EA / EAFs

QUESTINÁRIO

(Confidencial)

\section{Diagnóstico da Pecuária Leiteira do Estado de Goiás.}

Questionário $\mathbf{N}^{\circ}$

Data da entrevista:

Nome do entrevistador

Início da Entrevista:

Fim da Entrevista: 
Nome do Produtor:

Nome da Propriedade:

Município onde está a propriedade :

Distância: da propriedade ao "ponto" do leite da propriedade à sede do município da propriedade ao laticínio ou cooperativa $\mathrm{km}$ $\mathrm{km}$ $\mathrm{km}$

Cooperativa/laticínio que compra o leite:

Produção média vendida no último ano ( litros / dia ): Nas águas Na seca

1) Recursos disponíveis em outubro de 1997.

Tabela 1.1. Composição da área total da propriedade em outubro de 1997.

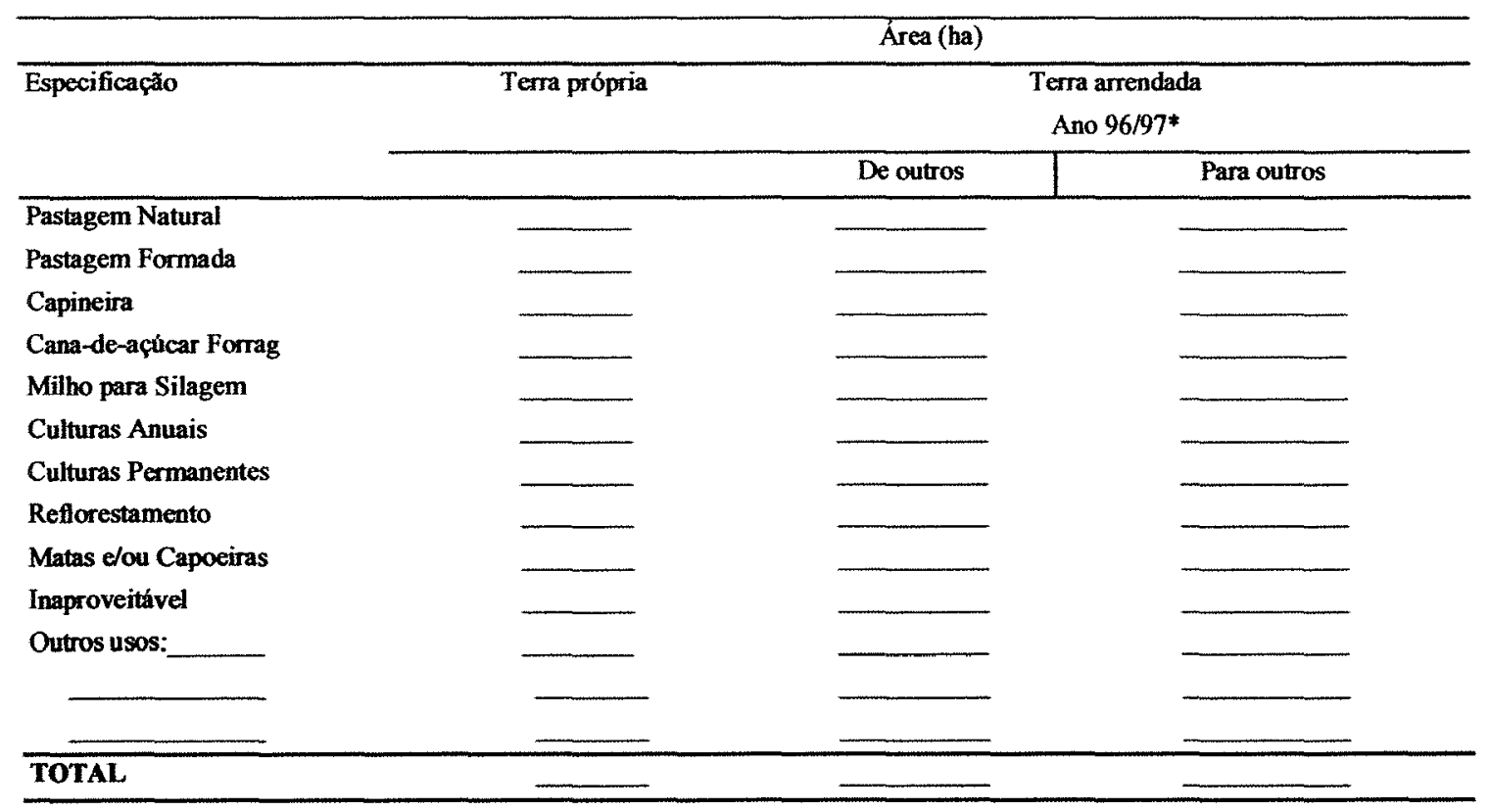

*Ano 96/97 = $1^{\circ}$ de julho de 1996 a 30 de junho de 1997

a)Preço médio da terra nua: $R$ \$/há:

b)Preço médio do aluguel de pasto na região:

$R \$ /$ cabeça adulta/mês

$\mathrm{R} \$ /$ ha /mês ou

litros de leite/cabeça/dia ou outros ou 
Tabela 1.2. Relação das benfeitorias utilizadas na pecuária de Leite em outubro de 1997.

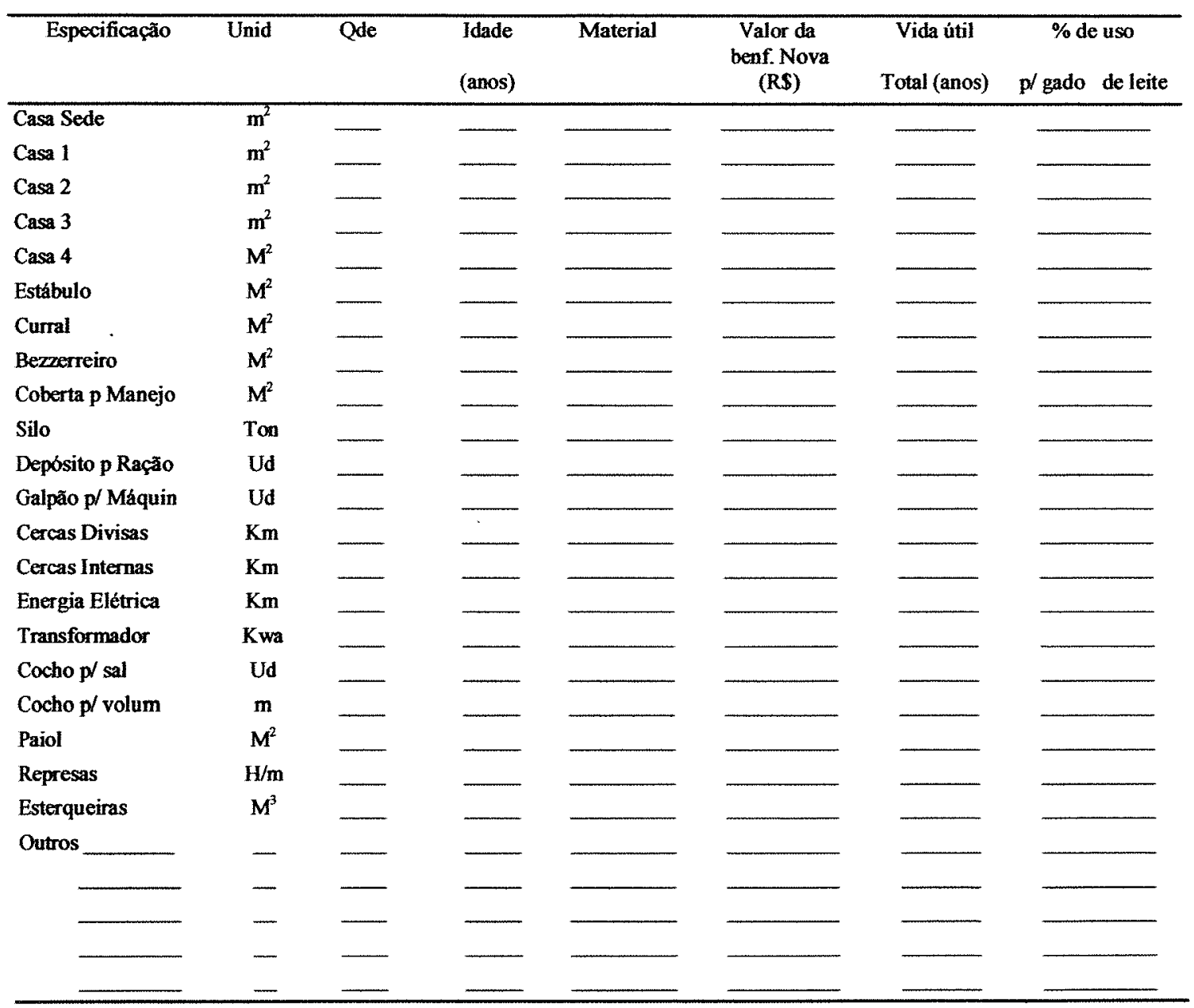

Gastos aproximados com reparos de benfeitorias no último ano, a preços de (out/1997): R\$

Observações:

No cálculo do valor da benfeitoria deve-se supor quanto custaria construir a benfeitoria em outubro de 1997. 
Tabela 1.3 Relação das máquinas, motores e equipamentos utilizados na pecuária de leite, outubro de 1997.

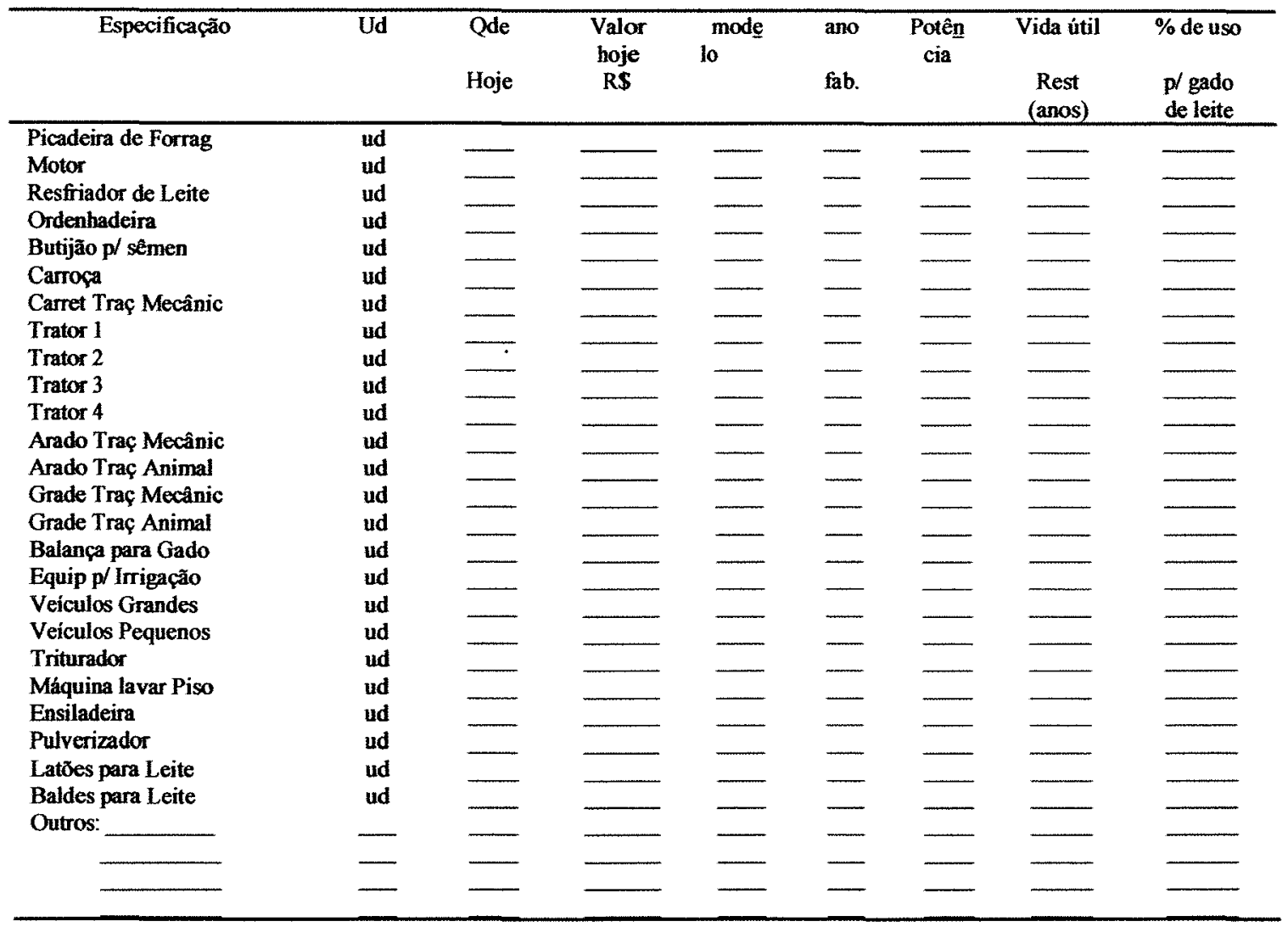

Gastos aproximados com reparos de máquinas, motores e equipamentos no último ano, a preços de outubro de 1997.

$\mathrm{R} \$$

Tabela 1.4. Relação do rebanho bovino, outubro de 1997.

\begin{tabular}{|c|c|c|c|}
\hline Categoria Animal & Quant hoje & Preco unit (RS) & Permanência na Faz \\
\hline Reprodutor & & & \\
\hline Vacas em Lactaçäo & & & \\
\hline Vacas Secas ou Falhadas & & & \\
\hline Novilhas para Reproduçăo & & & \\
\hline Novilhas de 1 a 2 anos & & & \\
\hline Bezerras Mamando & & & \\
\hline Bezerros Mamando & & & \\
\hline Machos p/Recria (1 a 2 anos) & & & \\
\hline Machos para Engorda & & & \\
\hline Rufioes & & & \\
\hline Bois de Carro & & & \\
\hline Eqüinos e Muares & & & \\
\hline Outros: & & & \\
\hline & & & \\
\hline
\end{tabular}


Tabela 1.5. Relação de Estoque de Insumos em outubro de 1997 ( colocar a unidade)

\begin{tabular}{l|c|c}
\hline \multicolumn{1}{c|}{ Especificação } & Unidade & Quantidade \\
\hline Adubo & & \\
\hline Óleo diesel & & \\
\hline Milho & & \\
\hline Ração & & \\
\hline Outros: & & \\
\hline & & \\
\hline
\end{tabular}

Tabela 1.6. Relação das dívidas em outubro de 1997.

\begin{tabular}{llll}
\hline Credor & Valor (RS) & Vencimento & Finalidade \\
\hline- & - & - \\
- & - & - \\
\hline
\end{tabular}


ANEXO 2 - Instruções e Ficha DIÁRIO para Coleta de Dados.

\section{FAVOR OBSERVAR AO PREENCHER O DIÁRIO}

RECEITAS: Anotar os valores dos produtos vendidos, prestação de serviços, aluguel de pastos, etc.

CONSUMO: Anotar as quantidades consumidas dos produtos da fazenda ( pelos empregados e proprietário ) e os usados na produção. Por exemplo: leite e derivados consumidos pelo proprietário, pelos empregados, utilizados na alimentação dos animais, esterco usado na horta, etc.

INVESTIMENTOS: Anotar os valores das compras de máquinas, implementos, animais e construções de benfeitoria.

GASTOS: Anotar os valores de todos os gastos e compras, mesmo que sejam a prazo. Por exemplo: pagamento de mão-de-obra quer seja mensalista, diarista ou empreitas; impostos, energia elétrica, telefone, assistência técnica, adubo, ração, sal, medicamentos, manutenção de máquinas, implementos e benfeitorias.

OBS: Anotar o valor de outros gastos com empregados, por exemplo: médico, remédio, transporte, roupas, etc.

Qualquer dúvida, telefone para (062) 521-1538 e entre em contato com os Professores Clayton, Dorival, Noronha ou Renato.

A pessoa que irá mensalmente a sua fazenda também poderá lhe ajudar. 


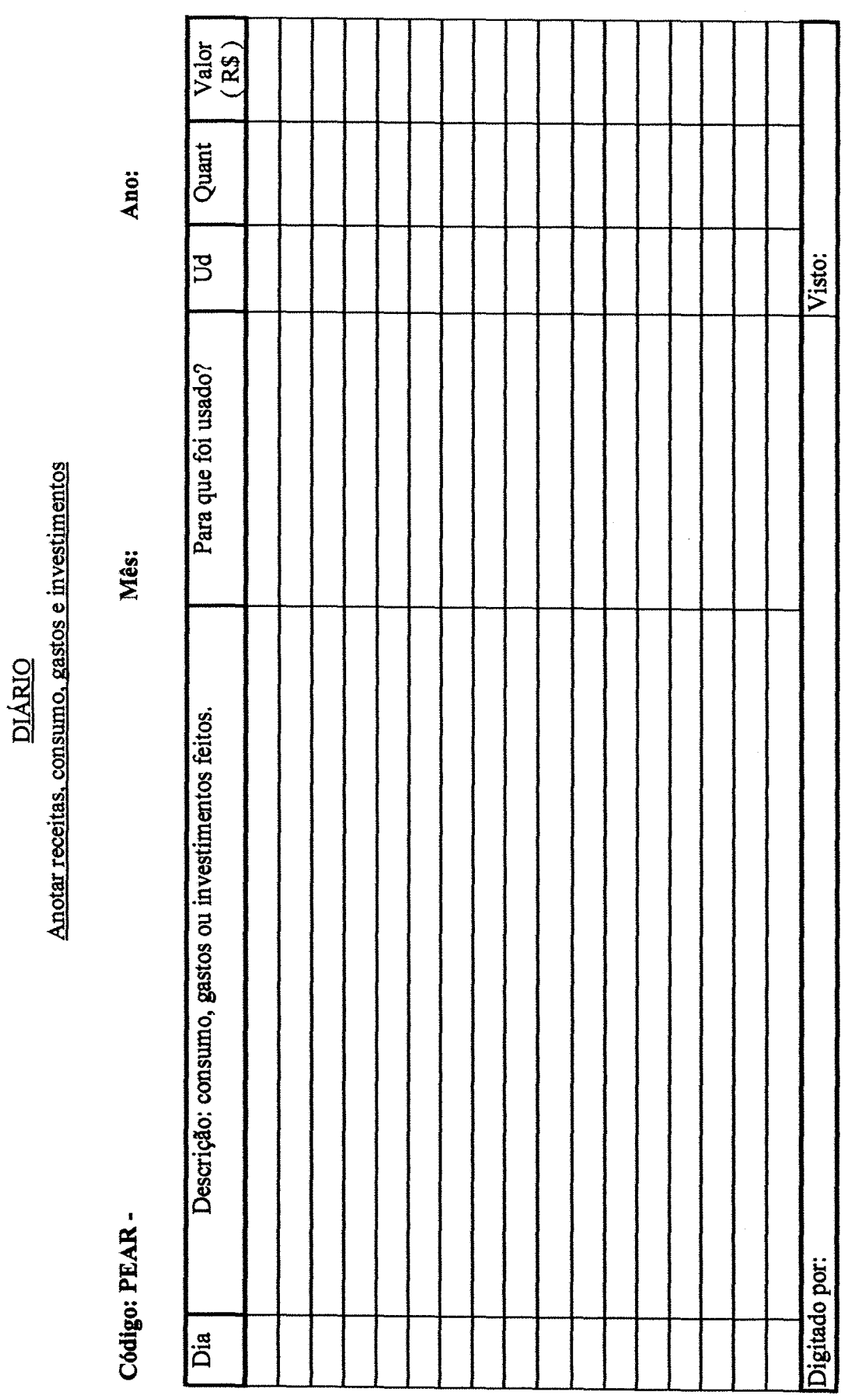


ANEXO 3 - Formulário para Acompanhamento do Controle de Rebanho.

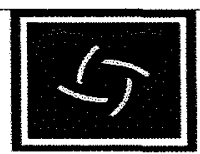

\section{PROGRAMA DE ESTÁGIO EM ADMINISTRAÇÃO RURAL - PEAR}

\section{Controle De Rebanho}

PEAR-

Data:

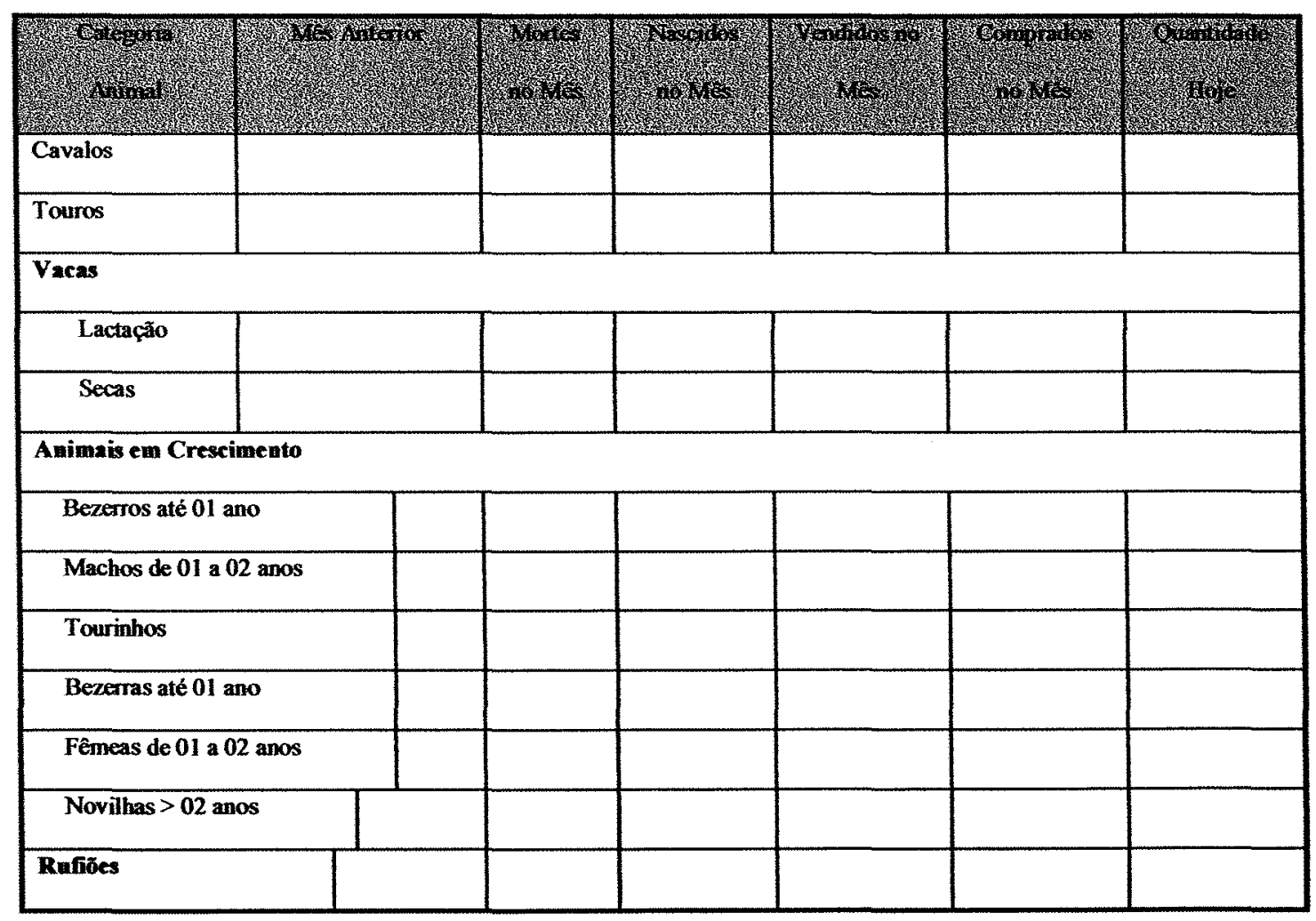


ANEXO 4 - Plano de Centro de Custo para Armazenamento de Dados.

\begin{tabular}{|l|l|}
\hline 01 & GADO DE LEITE \\
\hline $01,00,00$ & Produção de Leite \\
\hline $01,01,02$ & Recria da Bezerras \\
\hline $01,01,03$ & Outros atividades leiteiras \\
\hline $04,00,00$ & UNIDADES DE APOIO \\
\hline $04,01,01$ & Cantina, Dormitórios e Lazer \\
\hline $04,01,02$ & Mecanização e Oficinas \\
\hline $04,01,03$ & Tropa de Serviço \\
\hline $04,01,04$ & Apoio à Administração (contador, etc) \\
\hline $05,00,00$ & SEDE ADMINISTRATIVA \\
\hline $05,01,01$ & Residência \\
\hline $05,01,02$ & Veículos de Passeio e Viagens \\
\hline $05,01,03$ & Manutenção e Outros Gastos da Sede \\
\hline $06,00,00$ & OUTRAS CRIAÇÕES \\
\hline $06,01,01$ & Pequenos Animais \\
\hline $06,01,02$ & Médios Animais \\
\hline $06,01,03$ & Outros Grandes Animais \\
\hline $10,00,00$ & CULTURAS \\
\hline $10,01,01$ & Culturas Anuais \\
\hline $10,01,02$ & Culturas Semi-Perenes \\
\hline $10,01,03$ & Culturas Perenes \\
\hline
\end{tabular}


ANEXO 5 - Plano de Contas para Armazenamento de Dados.

\begin{tabular}{|c|c|c|c|c|}
\hline Coring & 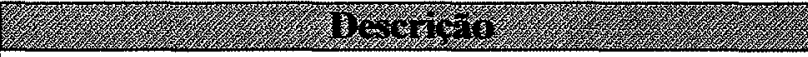 & 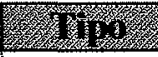 & (1) & 10.9. \\
\hline $3,0,00,000$ & RECEITA TOTAL & Receitas & $\mathrm{C}$ & Não \\
\hline $3,1,00,000$ & RECEITAS OPERACIONAIS & Receitas & $\mathrm{C}$ & Não \\
\hline $3,1,01,000$ & Receitas da Produção - CAIXA & Receitas & $\mathrm{C}$ & Não \\
\hline $3,1,01,001$ & Venda de leite & Receitas & $\mathrm{C}$ & Sim \\
\hline $3,1,01,002$ & Venda de matrizes & Receitas & $\mathrm{C}$ & Sim \\
\hline $3,1,01,003$ & Venda de reprodutores & Receitas & C & $\operatorname{Sim}$ \\
\hline $3,1,01,004$ & Venda de novilhos e bois magros & Receitas & C & Sim \\
\hline $3,1,01,005$ & Venda de novilhas & Receitas & C & Sim \\
\hline $3,1,01,006$ & Venda de descartes & Receitas & C & Sim \\
\hline $3,1,01,007$ & Venda de boi gordo e de derivados do leite & Receitas & $\mathrm{C}$ & Sim \\
\hline $3,1,01,008$ & Venda de bezerros (as) & Receitas & $\mathrm{C}$ & Sim \\
\hline $3,1,01,009$ & Venda de outros produtos & Receitas & C & Sim \\
\hline $3,1,02,000$ & Prestação de Serviços - CAIXA & Receitas & C & Não \\
\hline $3,1,02,001$ & Aluguel de máquinas, equipamentos e benfeitorias & Receitas & $\mathrm{C}$ & $\operatorname{Sim}$ \\
\hline $3,1,02,002$ & Aluguel de animais de trabalho & Receitas & $\mathrm{C}$ & Sim \\
\hline $3,1,02,003$ & Serviços prestados para terceiros & Receitas & $\mathrm{C}$ & Sim \\
\hline $3,1,02,004$ & Outras receitas operacionais caixa & Receitas & C & Sim \\
\hline $3,1,05,000$ & Receitas Operacionais NÃ̃-CAIXA & Receitas & $\mathrm{NC}$ & Não \\
\hline $3,1,05,001$ & Valor dos produtos consumidos & Receitas & NC & Sim \\
\hline $3,1,05,002$ & Valor dos pagamentos com produtos & Receitas & $\mathrm{NC}$ & Sim \\
\hline $3,1,05,003$ & Valor dos produtos usados na produção & Receitas & $\mathrm{NC}$ & Sim \\
\hline $3,1,05,004$ & Valor insumos/produtos recebidos & Receitas & NC & Sim \\
\hline $3,2,00,000$ & RECEITAS NÃOO OPERACIONAIS & Receitas & C & Não \\
\hline $3,2,01,000$ & Receitas Não-Operacionais - CAIXA & Receitas & $\mathrm{C}$ & Não \\
\hline $3,2,01,001$ & Ganhos nas vendas de bens de capital & Receitas & $\mathrm{C}$ & Sim \\
\hline $3,2,01,002$ & Aluguéis/arrendamentos para terceiros & Receitas & $\mathrm{C}$ & Sim \\
\hline $3,2,01,003$ & Juros de empréstimos a terceiros & Receitas & $\mathrm{C}$ & Sim \\
\hline $3,2,01,004$ & Juros de aplicações financeiras & Receitas & C & Sim \\
\hline $3,2,01,005$ & Outras receitas financeiras caixa & Receitas & C & Sim \\
\hline $3,2,01,006$ & Indenizações de seguros & Receitas & C & Sim \\
\hline $3,2,02,000$ & Receitas Não-Operacionais: NÃO-CAIXA & Receitas & $\mathrm{NC}$ & Não \\
\hline $3,2,02,001$ & Recebimentos em espécie & Receitas & $\mathrm{NC}$ & Sim \\
\hline $3,2,02,002$ & Doações, heranças etc., recebidas & Receitas & NC & Sim \\
\hline $4,0,00,000$ & CUSTO TOTAL DE PRODUÇÃO & Custos & C & Não \\
\hline $4,1,00,000$ & CUSTOS VARIÁVEIS DE PRODUÇÃO & Custos & C & Não \\
\hline $4,1,01,000$ & Mão-de-Obra Temporária & Custos & C & Não \\
\hline $4,1,01,001$ & Salários da mão-de-obra temporária & Custos & C & Sim \\
\hline $4,1,01,002$ & Encargos sociais M.O. temporária & Custos & $\mathrm{C}$ & Sim \\
\hline $4,1,01,003$ & Multas e encargos trabalhistas & Custos & C & Sim \\
\hline $4,1,01,004$ & Outros gastos com mão-de-obra & Custos & C & Sim \\
\hline $4,1,02,000$ & Serviços de Terceiros & Custos & $\mathrm{C}$ & Não \\
\hline $4,1,02,001$ & Aluguel veículos, máq. equip/implementos & Custos & $\mathrm{C}$ & Sim \\
\hline
\end{tabular}




\begin{tabular}{|c|c|c|c|c|}
\hline $4,1,02,002$ & Aluguel de animais de trabalho & Custos & $\mathrm{C}$ & $\operatorname{Sim}$ \\
\hline $4,1,02,003$ & Serviços de empreitada & Custos & $\mathrm{C}$ & $\mathrm{Sim}$ \\
\hline $4,1,02,004$ & Serviços de oficina externa & Custos & $\mathrm{C}$ & $\operatorname{Sim}$ \\
\hline $4,1,02,005$ & Consultoria técnica eventual & Custos & $\mathrm{C}$ & $\mathrm{Sim}$ \\
\hline $4,1,02,006$ & Outros serviços de terceiros & Custos & $\mathrm{C}$ & Sim \\
\hline $4,1,05,000$ & Serviços Mecanizados & Custos & C & Não \\
\hline $4,1,05,001$ & Combustivel e lubrificantes & Custos & C & Sim \\
\hline $4,1,05,002$ & Peças de reposição & Custos & C & $\operatorname{Sim}$ \\
\hline $4,1,05,003$ & Retífica, manutenção e reparos & Custos & C & $\operatorname{Sim}$ \\
\hline $4,1,06,000$ & Corretivos e Fertilizantes & Custos & $\mathrm{C}$ & Não \\
\hline $4,1,06,001$ & Corretivos e fertilizantes & Custos & C & $\mathrm{Sim}$ \\
\hline $4,1,08,000$ & Sementes e Mudas & Custos & C & Não \\
\hline $4,1,08,001$ & Sementes e mudas & Custos & C & $\mathrm{Sim}$ \\
\hline $4,1,14,000$ & Defensivos e Herbicidas & Custos & C & Não \\
\hline $4,1,14,001$ & Defensivos e herbicidas & Custos & $\mathrm{C}$ & $\operatorname{Sim}$ \\
\hline $4,1,15,000$ & Alimentos Concentrados & Custos & C & Não \\
\hline $4,1,15,001$ & Alimentos concentrados & Custos & $\mathrm{C}$ & $\mathrm{Sim}$ \\
\hline $4,1,15,002$ & Grãos para fabricar ração & Custos & $\mathrm{C}$ & Sim \\
\hline $4,1,15,003$ & Suplementos minerais & Custos & $\mathrm{C}$ & Sim \\
\hline $4,1,20,000$ & Alimentos Volumosos & Custos & $\mathrm{C}$ & Não \\
\hline $4,1,20,001$ & Volumoso pronto (feno, silagem) & Custos & C & Sim \\
\hline $4,1,20,002$ & Cultura para produção de volumoso & Custos & $\mathrm{C}$ & Sim \\
\hline $4,1,23,000$ & Inseminação Artificial & Custos & C & Não \\
\hline $4,1,23,001$ & Sêmen, luvas etc p/ inseminação & Custos & C & $\operatorname{Sim}$ \\
\hline $4,1,23,002$ & Serviços veterinários & Custos & $\mathrm{C}$ & Sim \\
\hline $4,1,24,000$ & Vacinas e Medicamentos & Custos & C & Não \\
\hline $4,1,24,001$ & Vacinas e medicamentos & Custos & $\mathrm{C}$ & Sim \\
\hline $4,1,25,000$ & Material de Consumo & Custos & $\mathbf{C}$ & Não \\
\hline $4,1,25,001$ & Material de consumo & Custos & C & Sim \\
\hline $4,1,27,000$ & Outros Custos Variáveis & Custos & $\mathrm{NC}$ & Não \\
\hline $4,1,27,001$ & Juros sobre o capital de custeio & Custos & $\mathrm{NC}$ & Sim \\
\hline $4,1,27,002$ & Valor insumos próprios (mudas, leite, etc) & Custos & NC & Sim \\
\hline $4,1,27,003$ & Outros custos variáveis não-caixa & Custos & $\mathrm{NC}$ & Sim \\
\hline $4,2,00,000$ & CUSTOS FIXOS DE PRODUÇÃO & Custos & $\mathrm{C}$ & Não \\
\hline $4,2,01,000$ & Mão-de-Obra Permanente & Custos & $\mathrm{C}$ & Não \\
\hline $4,2,01,001$ & Salário da mão-de-obra permanente & Custos & C & Sim \\
\hline $4,2,01,002$ & Encargos sociais M.O. permanente & Custos & $\mathrm{C}$ & Sim \\
\hline $4,2,01,003$ & Rescisões, encargos e multas trabalhistas & Custos & $\mathrm{C}$ & Sim \\
\hline $4,2,02,000$ & Manutenção e Reparos & Custos & C & Não \\
\hline $4,2,02,001$ & Manutenção e reparos de benfeitorias e construções & Custos & $\mathrm{C}$ & Sim \\
\hline $4,2,02,002$ & Manutenção e reparos de melhoramentos fundiários & Custos & C & Sim \\
\hline $4,2,03,000$ & Aluguéis e Arrendamentos Fixos & Custos & C & Não \\
\hline $4,2,03,001$ & Aluguel de pastagens de terceiros & Custos & C & Sim \\
\hline $4,2,03,002$ & Arrendamento de terras de Terceiros & Custos & $\mathrm{C}$ & Sim \\
\hline $4,2,04,000$ & Taxas, Impostos, Seguros e Licenças & Custos & C & Não \\
\hline $4,2,04,001$ & Taxas e impostos sobre propriedade & Custos & $\mathrm{C}$ & Sim \\
\hline
\end{tabular}




\begin{tabular}{|c|c|c|c|c|}
\hline $4,2,04,002$ & Seguros e licenças sobre propriedade & Custos & $\mathrm{C}$ & $\operatorname{Sim}$ \\
\hline $4,2,05,000$ & Depreciações & Custos & $\mathrm{NC}$ & Não \\
\hline $4,2,05,001$ & Depreciação de veículos & Custos & NC & Sim \\
\hline $4,2,05,002$ & Depreciação de maquinaria & Custos & NC & Sim \\
\hline $4,2,05,003$ & Depreciação de equipamentos & Custos & $\mathrm{NC}$ & Sim \\
\hline $4,2,05,004$ & Depreciação de implementos & Custos & $\mathrm{NC}$ & Sim \\
\hline $4,2,05,005$ & Depreciação de construções e instalações & Custos & NC & Sim \\
\hline $4,2,05,006$ & Depreciação de animais & Custos & $\mathrm{NC}$ & Sim \\
\hline $4,2,05,007$ & Depreciação de culturas perenes & Custos & $\mathrm{NC}$ & Sim \\
\hline $4,2,07,000$ & Outros Custos Fixos Não-Caixa & Custos & $\mathrm{NC}$ & Não \\
\hline $4,2,07,001$ & Seguros imputados & Custos & NC & Sim \\
\hline $4,2,07,002$ & Juros imputados sobre bens e animais & Custos & $\mathrm{NC}$ & Sim \\
\hline $4,2,07,003$ & Valor imputado da mão-de-obra familiar & Custos & $\mathrm{NC}$ & Sim \\
\hline $4,2,07,004$ & Valor da moradia e alimentação fornecida & Custos & $\mathrm{NC}$ & Sim \\
\hline $4,2,07,005$ & Valor de uso das pastagens naturais & Custos & $\mathrm{NC}$ & Sim \\
\hline $4,2,07,006$ & Valor de uso das outras terras próprias & Custos & $\mathrm{NC}$ & Sim \\
\hline $4,2,07,007$ & Outros custos fixos não-caixa & Custos & $\mathrm{NC}$ & Sim \\
\hline $5,0,00,000$ & DESPESA TOTAL DA FAZENDA & Despesas & C & Sim \\
\hline $5,1,00,000$ & DESPESAS OPERACIONAIS & Despesas & C & Não \\
\hline $5,1,01,000$ & Despesas com Vendas & Despesas & C & Não \\
\hline $5,1,01,001$ & Taxas e comissões de vendas & Despesas & C & $\operatorname{Sim}$ \\
\hline $5,1,01,002$ & Transporta externo & Despesas & $\mathrm{C}$ & Sim \\
\hline $5,1,01,003$ & Armazenamento externo & Despesas & C & Sim \\
\hline $5,1,01,004$ & Embalagens & Despesas & C & Sim \\
\hline $5,1,01,005$ & Outras despesas de comercialização & Despesas & C & Sim \\
\hline $5,1,02,000$ & Despesas Administrativas & Despesas & C & Não \\
\hline $5,1,02,001$ & Retiradas do(s) proprietário(s) & Despesas & $\mathrm{C}$ & Sim \\
\hline $5,1,02,002$ & $\begin{array}{l}\text { Viagens a serviço } \\
\end{array}$ & Despesas & $\mathrm{C}$ & Sim \\
\hline $5,1,02,003$ & Despesas do escritório & Despesas & C & Sim \\
\hline $5,1,02,004$ & Consultoria profissional & Despesas & C & Sim \\
\hline $5,1,02,005$ & Despesas jurídicas não trabalhistas & Despesas & C & Sim \\
\hline $5,1,02,006$ & Serviços de contabilidade & Despesas & C & Sim \\
\hline $5,1,02,007$ & Energia elétrica, telefone, fax etc & Despesas & $\mathrm{C}$ & Sim \\
\hline $5,1,02,008$ & Outras despesas administrativas & Despesas & C & Sim \\
\hline $5,1,03,000$ & Despesas Financeiras & Despesas & C & Não \\
\hline $5,1,03,001$ & Despesas com fornecedores & Despesas & $\mathrm{C}$ & Sim \\
\hline $5,1,03,002$ & Despesas com empréstimos & Despesas & $\mathrm{C}$ & Sim \\
\hline $5,1,03,003$ & Despesas bancárias (IOF, cartões) & Despesas & C & Sim \\
\hline $5,1,03,004$ & Outras despesas financeiras (juros e multas) & Despesas & $\mathrm{C}$ & Sim \\
\hline $5,2,00,000$ & OUTRAS DESPESAS & Despesas & $\mathrm{NC}$ & Não \\
\hline $5,2,01,000$ & Outras Despesas & Despesas & $\mathrm{NC}$ & Não \\
\hline $5,2,01,001$ & Consumo interno (sede e funcionários) & Despesas & $\mathrm{NC}$ & Sim \\
\hline $5,2,01,002$ & Remuneração do proprietário & Despesas & $\mathrm{NC}$ & $\operatorname{Sim}$ \\
\hline $5,2,01,003$ & Pagamento de compras, com produtos & Despesas & $\mathrm{NC}$ & Sim \\
\hline
\end{tabular}




\section{REFERÊNCIAS BIBLIOGRÁFICAS}

ASSUMPÇÃO, R.; VEIGA, J.E.R. A aplicação da administração por objetivos na gestão do negócio de cooperativas de assentamento rural no Brasil. Informações Econômicas, v.30, n.9, p.7-22, set.2000. (Série Técnica APTA)

BRANDÃO, A.S.P. Aspectos econômicos e institucionais da produção de leite no Brasil. In: VILELA, D.; BRESSAN, M.; CUNHA, A.S. (Ed.). Restrições téenicas, econômicas e institucionais ao desenvolvimento da cadeia produtiva do leite no Brasil: Região Centro-Oeste. Juiz de Fora: EMBRAPA, 1999. cap.2, p.37-70: Aspectos econômicos e institucionais da produção de leite no Brasil.

BRESSAN, M.; MOREIRA, P.; VERNEQUE, R.S.; JONES, A. da S. Tecnologias utilizadas pelos produtores de leite de Goiás e suas relações com questões de sustentabilidade e competitividade do segmento da produção. In: SIMPÓSIO SUSTENTABILIDADE DA PECUÁRIA DE LEITE NO BRASIL, 1., Goiânia, 1999. Anais. Goiânia: EMBRAPA, 1999. p.21-44.

BRESSAN, M.; VERNEQUE, R.S.; MOREIRA, P. A produção de leite em Goiás. Juiz de Fora: EMBRAPA, 1999. 310p.

CANZIANI, J.R.F. Uma abordagem sobre as diferenças de metodologias utilizadas no cálculo do custo total de produção da atividade leiteira a nível individual (produtor) e a nível regional. In: SEMINÁRIO SOBRE METODOLOGIAS DE CÁLCULO DO CUSTO DE PRODUÇÃO DE LEITE, 1., Piracicaba, 1999. Anais. Piracicaba: CEPEA, 1999. p.13-23. 
BACHMAN, K.L.; CHRISTENSEN, R.P. The economics of farm size. In: COHEN, R.L. Agricultural development and economic growth. Cambridge: Company Limited and Cambridge University Press, 1956. chap.7, p.234-266: The economics of farm size.

FAO. Statistical databases. htpp://www.fao.org (15 May 1999)

FEDERAÇÃO DA AGRICULTURA DO ESTADO DE MINAS GERAIS. Diagnóstico. da pecuária leiteira do Estado de Minas Gerais. Belo Horizonte: SEBRAE-MG, 1996. p.102-202.

FELLET, V.K.; GALLAN, V.B. Diagnóstico e acompanhamento financeiro da atividade leiteira. Preços Agrícolas, v.14, n.160, p.14-17, fev. 2000.

FIGUEIREDO, R.S. Sistemas de apuração de custos. In: BATALHA, M.D. (Coord.). Gestão agroindustrial. São Paulo: Atlas, 1997. p.348-435.

FNP CONSULTORIA \& COMÉRCIO. Anualpec 99: Anuário da Pecuária Brasileira. São Paulo, 1999. p.233-292.

GERALDINE, D.G.; NORONHA, J.F.; XAVIER, L.E.; SILVA JUNIOR, R.P.; MUNDIN, S.P. Proposta de gestão da atividade leiteira em Goiás. Goiânia: UFG, 1999. 15p.

GOIÁS. Secretaria do Planejamento e Desenvolvimento Regional. Superintendência de Estatística, Pesquisa e Informação. Anuário estatístico de Goiás. Goiânia: SEPLAN-GO/SEPIN, 1995-1999. 
GOMES, S.T. Cuidados no cálculo do custo de produção de leite. In: SEMINÁRIO SOBRE METODOLOGIAS DE CÁlCULO DO CUSTO DE PRODUÇÃO DE LEITE, 1., Piracicaba, 1999. Anais. Piracicaba: CEPEA, 1999. p.32-42.

GOMES, S.T. Diagnóstico e perspectivas da produção de leite no Brasil. In: VILELA, D.; BRESSAN, M.; CUNHA, A.S. (Ed.). Restriçōes técnicas, econômicas e institucionais ao desenvolvimento da cadeia produtiva do leite no Brasil: Região Centro-Oeste. Juiz de Fora: EMBRAPA-CNPGL, 1999. cap.1, p.19-36: Diagnóstico e perspectivas da produção de leite no Brasil.

HOFFMANN, R.; ENGLER, J.J. de C.; SERRANO, O.; THAME, A.C. de M.; NEVES, E.M. Administração da empresa agrícola. 4.ed. São Paulo: Pioneira, 1984. p.5762.

INSTITUTO BRASILERIRO DE GEOGRAFIA E ESTATÍsticA. Censo agropecuário 1995-1996. Rio de Janeiro: IBGE, 1997.

JANK, F.S. Produção de leite: afinal, qual é o melhor sistema? Preços Agrícolas, v.12, n.119, p.25-32, nov.1996.

JANK, M.S.; FARINA, E.M.Q.; GALLAN, V.B. O agribussines do leite no Brasil. São Paulo: Milkbizz, 1999. 108p.

LEITE, H. de P. Contabilidade para administradores. São Paulo: Atlas, 1988. 518p.

LEMES, S. Contabilidade na agropecuária. In: MARION, J.C. (Coord.). Contabilidade e controladoria em agribusiness. São Paulo: Atlas, 1996. cap.2, p.30-42: Contabilidade na agropecuária. 
LEONE, G.S.G. Custos: planejamento, implantação e controle. 2.ed. São Paulo: Atlas, 1996. 512p.

MARION, J.C. Contabilidade empresarial. São Paulo: Atlas, 1998. 514p.

MARTINS, E. Contabilidade de custos: inclui o ABC. 5.ed. São Paulo: Atlas, 1996. $381 p$.

MATTOS, Z.P. de B. Contabilidade financeira rural. São Paulo: Atlas, 1999. 196p.

NORONHA, J.F.; ALCÂNTARA, J.M.; PETRI, M.A. de A. Custo de produção e análise econômica da atividade leiteira. Piracicaba: FEALQ, 1990. 53p.

NORONHA, J.F.; SILVA JUNIOR, R.P.; GERALDINE, D.G. Análise da rentabilidade da atividade leiteira no Estado de Goiás. In: SEMINÁRIO SOBRE METODOLOGIAS DE CÁlCULO DO CUSTO DE PRODUÇÃo DE LEITE, 1., Piracicaba, 1999. Anais. Piracicaba: CEPEA, 1999. p.4-12.

NORONHA, J.F.; NUNES, C.L. de M.; GERALDINE, D.G.; SILVA JUNIOR, R.P. Análise da rentabilidade da atividade leiteira no Estado de Goiás. 1.ed. Goiânia: UFG, 2001. 106p.

NUNES, C.L. de M.; NORONHA, J.F.; SILVA JUNIOR, R.P.; GERALDINE, D.G. Lucratividade da atividade leiteira em Goiás. In: CONGRESSO BRASILEIRO DE ADMINISTRAÇÃO RURAL, 3., Goiânia, 1999. Anais. Belo Horizonte: ABAR, 1999. p.336-347.

NUNES, C.L. de M.; NORONHA, J.F.; SILVA JUNIOR, R.P.; GERALDINE, D.G. Lucratividade da atividade leiteira em Goiás. Cadernos de Administração Rural, v.10, n.2, p.65-76, jul./dez. 1998. 
PADOVEZE, L.C. Contabilidade gerencial: um enfoque em sistema de informação contábil. São Paulo: Atlas, 1996. 392p.

PFALTZGRAFF, R. Manual de análise de balanço. 2.ed. São Paulo: Cultrix, 1985. $203 p$.

PROCÓPIO, A.M. Organização contábil-administrativa dos produtores rurais na região de Ribeirão Preto. In: MARION, J.C. (Coord.). Contabilidade e controladoria em agribusiness. São Paulo: Atlas, 1996. cap.1, p.19-29: Organização contábiladministrativa dos produtores rurais na região de Ribeirão Preto.

RENTERO, N. Leite de Goiás avança e muda o perfil da produção no país. Balde Branco, v.33, n.392, p.36-43, jun. 1997.

ROSS, S.A.; WESTERFIELD, H.W.; JAFFE, J.F. Administração financeira. São Paulo: Atlas, 1995.698p.

SAMUELSON, P.A.; NORDHAUS, W.D. Economia. 14.ed. São Paulo: McGraw-Hill, 1992. p.7-9.

SANTOS, G.J. dos; MARION, J.C. Administração de custos na agropecuária. 2.ed. São Paulo: Atlas, 1996. p.13-52.

SILVA, J.P. da. Análise financeira das empresas. 3.ed. São Paulo: Atlas, 1995. 484p.

SOUZA, R. de; GUIMARÃES, J.M.P.; VIEIRA, G.; MORAES, V.A.; ANDRADE, J.G. A administração da fazenda. 5.ed. São Paulo: Globo, 1995. 201p. (Coleção do Agricultor - Economia) 
TOLEDO, C.P. Custo de produção e análise econômica da atividade leiteira. htpp://www.geroleite.com.Br/trab.html (15 mar. 2001)

VILELA, D. C\&T no agronegócio do leite. In: SEMINÁRIO SOBRE IDENTIFICAÇÃO DE RESTRIÇÕES TÉCNICAS, ECONÔMICAS E INSTITUCIONAIS AO DESENVOLVIMENTO DO SETOR LEITEIRO NACIONAL, 1., Goiânia, 1998. Anais. Goiânia: EMBRAPA, 1998. p.15-24.

WALTER, M.A.; BRAGA, H.R. Demonstrações financeiras: um enfoque gerencial. São Paulo: Atlas, 1981. v.2, p.23-165. 